\title{
Extreme Meteorological Events in a Coastal Lagoon Ecosystem: The Ria de Aveiro Lagoon (Portugal) Case Study
}

\author{
José Fortes Lopes*(D), Carina Lurdes Lopes (D) and João Miguel Dias (D) \\ CESAM, Departamento de Física, Universidade de Aveiro, 3810-193 Aveiro, Portugal; carinalopes@ua.pt (C.L.L.); \\ joao.dias@ua.pt (J.M.D.) \\ * Correspondence: jflopes@ua.pt; Tel.: +351-234-370-821
}

check for updates

Citation: Lopes, J.F.; Lopes, C.L.; Dias, J.M. Extreme Meteorological Events in a Coastal Lagoon Ecosystem: The Ria de Aveiro Lagoon (Portugal) Case Study. J. Mar. Sci. Eng. 2021, 9, 727. https://doi.org/ $10.3390 /$ jmse9070727

Academic Editor: Thomas Lippmann

Received: 2 May 2021

Accepted: 25 June 2021

Published: 30 June 2021

Publisher's Note: MDPI stays neutral with regard to jurisdictional claims in published maps and institutional affiliations.

Copyright: (c) 2021 by the authors. Licensee MDPI, Basel, Switzerland. This article is an open access article distributed under the terms and conditions of the Creative Commons Attribution (CC BY) license (https:// creativecommons.org/licenses/by/ $4.0 /)$.

\begin{abstract}
Extreme weather events (EWEs) represent meteorological hazards for coastal lagoon hydrodynamics, of which intensity and frequency are increasing over the last decades as a consequence of climate changes. The imbalances they generated should affect primarily vulnerable low-lying areas while potentially disturbing the physical balances (salt and water temperature) and, therefore, the ecosystem equilibrium. This study arises from the need to assess the impact of EWEs on the Ria de Aveiro, a lagoon situated in the Portuguese coastal area. Furthermore, it was considered that those events occur under the frame of a future sea-level rise, as predicted by several climate change scenarios. Two EWEs scenarios, a dry and an extremely wet early summer reflecting past situations and likely to occur in the future, were considered to assess the departure from the system baseline functioning. It was used as a biogeochemistry model that simulates the hydrodynamics, as well as the baseline physical and biogeochemistry state variables. The dry summer scenario, corresponding to a significant reduction in the river's inflow, evidences a shift of the system to a situation under oceanic dominance characterized by colder and saltier water $\left(\sim 18{ }^{\circ} \mathrm{C}\right.$; 34 PSU) than the baseline while lowering the concentration of the nutrients and reducing the phytoplankton population to a low-level limit. Under a wet summer scenario, the lagoon shifted to a brackish and warmer situation $\left(\sim 21{ }^{\circ} \mathrm{C},<15 \mathrm{PSU}\right)$ in a time scale of some tidal periods, driven by the combining effect of the tidal transport and the river's inflow. Phytoplankton patterns respond to variability on local and shortterm scales that reflect physical conditions within the lagoon, inducing nutrient-supported growth. Overall, the results indicate that EWEs generate local and transient changes in physical conditions (namely salinity and water temperature) in response to the characteristic variability of the lagoon's hydrodynamics associated with a tidal-dominated system. Therefore, in addition to the potential impact of changing physical conditions on the ecosystem, saline intrusion along the lagoon or the transfer of brackish water to the mouth of the system are the main consequences of EWEs, while the main biogeochemistry changes tend to remain moderate.
\end{abstract}

Keywords: Ria de Aveiro Lagoon; extreme weather events; hydrodynamics; biogeochemistry; climate change

\section{Introduction}

Extreme weather events (EWEs) are currently associated with climate changes and can be understood as extreme weather events that can manifest as maximum or minimum daily air temperature or precipitation. In this context, heatwaves, extreme dryness situations, storm surges, or high-amplitude ocean waves can be seen as EWE cases [1,2]. Being monitored and studied for several decades [1-7], it is today evident that EWEs have seen their intensity and frequency increased over the last decades. Since the Fifth Assessment Report of the Intergovernmental Panel on Climate Change [8], the EWEs assessment has improved and is predicted to become more common in the future, following the global warming trend. Furthermore, EWEs are taking place under the sea-level rise (SLR) threat, which itself is a direct consequence of global warming [9]. Indeed, sea level has increased 
by approximately $190 \mathrm{~mm}$ over the period 1901-2010 [10] in response to global warming, and it is expected to increase between 0.26 and $0.82 \mathrm{~m}$ by 2100 [11-16], although there is uncertainty in the different projections. In particular, sea level on the Portuguese coast has been reported to have increased at a rate of $2.1 \pm 0.1 \mathrm{~mm} /$ year, with an increase of $0.47 \mathrm{~m}$ in 2100 compared to 1990, with a confidence interval of $95 \%$ between 0.19 and $0.75 \mathrm{~m}[17,18]$. EWEs may affect water circulation patterns in estuarine systems, inducing local morphodynamical changes. These systems are also threatened by storm surges, increasing the risk of coastal flooding by extreme water levels [19], while sudden changes in the river discharges induce changes in the physical and biogeochemistry patterns of the water column (e.g., residual circulation, salinity, water temperature, turbidity, nutrient distribution, phytoplankton population, dissolved oxygen, etc.). The imbalances generated by those events in the frame of SLR may represent risks to vulnerable low-lying areas, not only due to the ecosystem morphological changes but also due to the community adaptation challenges to the new environment [20-34]. Ria de Aveiro, located at the NW coast of Portugal, is a coastal lagoon extremely vulnerable to climate change impacts, namely to sea-level rise.

Previous studies assessed the status of the Ria de Aveiro Lagoon (Portugal) under sealevel rise, namely the flood risk assessment of the lagoon margins [35-38], as well as changes in the lagoon salinity patterns [39] and the distribution of physical and biogeochemistry variables [40]. The results point out an overall salinity increase in the lagoon and a decrease in water temperature as well as inorganic nitrogen and carbon phytoplankton concentrations due to the increased exchanges with the ocean. The present study arises from the need to investigate the impact of EWEs in the study area, likely to occur in the future. Therefore, this work has the purpose of assessing the status of the lagoon water column under EWE scenarios in the framework of the SLR scenario, as predicted for the coastal area $[17,18]$. In particular, it will assess the departure from the baseline configuration of the main physical and biogeochemistry state variables. The methodology followed comprises the exploitation of a previously developed physical and biogeochemistry coupled model of the lagoon [40].

\section{The Study Area}

Ria de Aveiro (Figure 1) is a shallow coastal well-mixed lagoon (average depth of $1 \mathrm{~m}$ ), located on the Northwest Atlantic coast of Portugal $\left(40^{\circ} 38^{\prime} \mathrm{N}, 8^{\circ} 45^{\prime} \mathrm{W}\right)$, connected to the sea through a narrow entrance. Among the four main channels, Ilhavo, Mira, S. Jacinto, and Espinheiro, the latter two are responsible for most of the saltwater and freshwater exchanges (Figure 1).

The lagoon hydrodynamics are essentially dominated by semi-diurnal tides, with a tidal prism at the lagoon mouth of about $65.89 \times 10^{6}$ and $139.79 \times 10^{6} \mathrm{~m}^{3}$ for neap and spring tide conditions, respectively. Tidal amplitude reaches values as high as $4 \mathrm{~m}$ during the spring-neap tide, while tidal currents are strongest near the lagoon mouth, where they reach maximum intensities up to $2 \mathrm{~ms}^{-1}$ [41,42]. The currents in the central area still have strong intensities $\left(<1 \mathrm{~ms}^{-1}\right)$ that progressively decay to low values toward the intertidal areas and narrow channels $\left(\sim 0.1 \mathrm{~m} \mathrm{~s}^{-1}\right)$ [41]. Therefore, the residence time ranges between some tidal periods up to two weeks $[42,43]$ from the lagoon mouth toward the channel's heads. The lagoon has experienced some morphodynamical changes, from both natural (SLR) and anthropogenic origins, which affected its hydrodynamics. For instance, the amplitude of the $M_{2}$ tidal constituent has increased by a rate of $2.8 \mathrm{~mm} \mathrm{yr}^{-1}$ between 1976 and 2013 at the lagoon entrance, while the sea level increased at a rate of $2.2 \pm 0.1 \mathrm{~mm} \mathrm{yr}^{-1}$ [35-37].

Two main rivers contribute to the lagoon's main freshwater supply, Vouga and Antuã, situated at the eastern boundary of the lagoon, with estimated average flows up to 50 and $5 \mathrm{~m}^{3} \mathrm{~s}^{-1}$ [44] and 80 and $20 \mathrm{~m}^{3} \mathrm{~s}^{-1}$ [39], respectively. Several other small rivers (Cáster, Boco, and Ribeira dos Moínhos) discharge at the lagoon northern and southern boundaries, with average flows below $5 \mathrm{~m}^{3} \mathrm{~s}^{-1}$. 
Winds and waves, compared to the tides, play a minor role in the lagoon hydrodynamics. The maximum contribution of wind stress on water levels is typically lower than 0.05 [45], while waves with a significant height of $4 \mathrm{~m}$ only produce over-elevations of approximately $0.2 \mathrm{~m} \mathrm{[46].}$

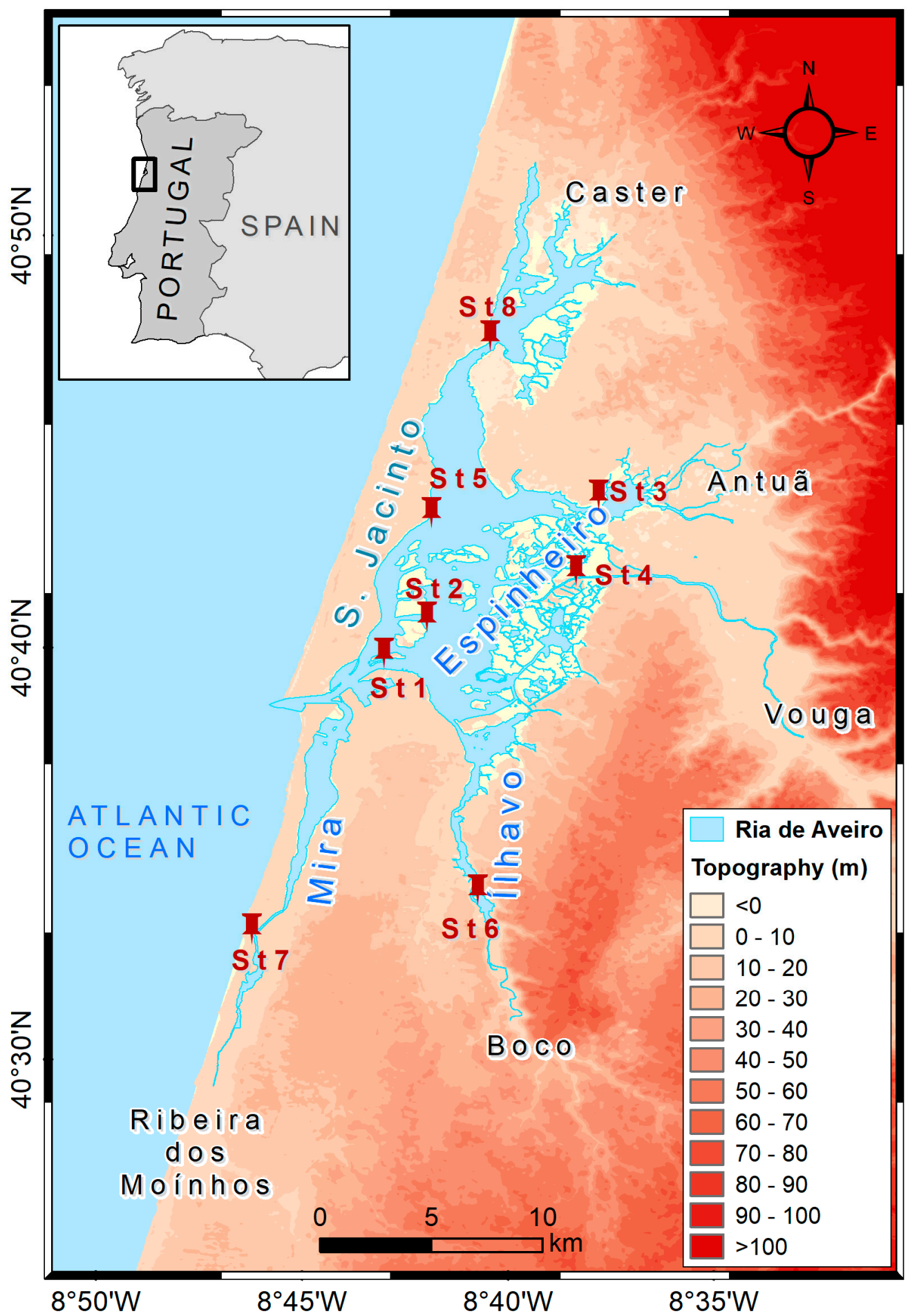

Figure 1. The study area: The Ria de Aveiro Lagoon, with the location of the stations used in this work (St).

The Aveiro coastal area has experienced in the recent decades' episodes of intense precipitation and dryness, reflected in significant changes in the salinity, water temperature, and main biogeochemistry state variables lagoon patterns. Indeed, Tables 1 and 2 
summarize data collected by several authors [47-51] from summer 2000 to autumn 2001 in the main lagoon stations (Figure 1). Summer corresponds, in general, to a dry season characterized by typical salinity patterns of the lagoon induced by small to moderate river discharges. The salinity distribution presents, in general, a well-established gradient, corresponding to high values at the ocean boundary (30-34 PSU) and low values ( $<5$ PSU) at the far end of the channels (stations 3, 4, 6, 7 and 8), with intermediate values (15-20 PSU) observed for the remaining areas. During the wet season, which may last from late autumn to early spring, extreme low salinity values were observed inside the lagoon in response to high precipitation episodes. For instance, during the period covering late autumn 2000 and early spring 2001, the rainfall reached pick values as high as $757 \mathrm{~mm}$, and the salinity showed extremely low values (Table 1). Indeed, St1 and St2 showed extremely low values (7-20 PSU), despite their location close to the lagoon mouth.

The water temperature shows typical lagoon summer warm waters $\left(19-22{ }^{\circ} \mathrm{C}\right)$. It should point out that the minimum value is relatively high, as, during the summer period, the lagoon may be under the influence of deep upwelled ocean waters $\left(\sim 17-18^{\circ} \mathrm{C}\right)$.

Regarding the biogeochemistry variables (Table 2 ), high concentration values were observed throughout the main stations. Nitrogen and phosphorus are in general available from river runoff inputs, including sewage, industrial, and agricultural sources. Indeed, high values of nitrate and nitrites $\left(\mathrm{NO}_{3}+\mathrm{NO}_{2}\right)\left(>3.5 \mathrm{mg} \mathrm{L}^{-1}\right)$ and phosphates $\left(\mathrm{PO}_{4}\right)$ $\left(<0.4 \mathrm{mg} \mathrm{L}^{-1}\right)$ concentrations were reported [49-51], as can be observed in Table 2. Furthermore, Lopes et al. [51] assessing the relative proportion of available nutrients in the Ria during late autumn and winter, and during latespring and summer, relatively to the Redfield stoichiometry [52], point out to a large excess of nitrogen, relatively to phosphorus, particularly the oxidised form (nitrate), and silica.

Table 1. Salinity and water temperature extreme values observed for the main lagoon stations from September 2000 to September 2001 according to observations performed under wet and dry conditions [47-51].

\begin{tabular}{ccccc}
\hline Stations & Min. & $\begin{array}{c}\text { Salinity Wet } \\
\text { (PSU) }\end{array}$ & $\begin{array}{c}\text { Salinity Dry } \\
\text { (PSU) }\end{array}$ & $\begin{array}{c}\text { Water Temperature } \\
\left({ }^{\circ} \mathbf{C}\right)\end{array}$ \\
\hline \multirow{2}{*}{ St1 } & 7.8 & 32.5 & 18.5 \\
& Max. & 18 & 35.1 & 20.8 \\
St2 & Min. & 0.1 & 33.6 & 18.9 \\
& Max. & 4.8 & 34.4 & 20.2 \\
St3 & Min. & 0.6 & 32.7 & 19.6 \\
& Max. & 7 & 33.8 & 20.4 \\
St4 & Min. & 0.0 & 30.0 & 19.81 \\
& Max. & 0.0 & 30.0 & 20.6 \\
St5 & Min. & 2 & 34.1 & 18.4 \\
& Max. & 11 & 34.7 & 19.2 \\
\multirow{3}{*}{ St7 } & Min. & 1.0 & 32.5 & 20.1 \\
& Max. & 11 & 34.4 & 21.0 \\
& Min. & 1.0 & 29.2 & 20.2 \\
\hline
\end{tabular}


Table 2. Extreme values for the biogeochemistry state variables, observed for the main lagoon stations from September 2000 to September 2001 [47-51].

\begin{tabular}{|c|c|c|c|c|c|c|c|}
\hline Stations & & $\begin{array}{c}\mathrm{NI} \\
\left(\mathrm{mg} \mathrm{L}^{-1}\right)\end{array}$ & $\begin{array}{c}\text { PI } \\
\left(\mathrm{mg} \mathrm{L}^{-1}\right)\end{array}$ & $\begin{array}{c}\mathrm{Si} \\
\left(\mathrm{mg} \mathrm{L}^{-1}\right)\end{array}$ & $\begin{array}{c}\text { DO } \\
\left(\mathrm{mg} \mathrm{L}^{-1}\right)\end{array}$ & $\begin{array}{c}\text { Chl } \\
\left(\mu \mathrm{g} \mathrm{L}^{-1}\right)\end{array}$ & $\begin{array}{c}\mathrm{PC} \\
\left(\mathrm{mg} \mathrm{L}^{-1}\right)\end{array}$ \\
\hline \multirow{2}{*}{ St1 } & Min. & 0.5 & 0.01 & 0.7 & 10.0 & 0.6 & 0.1 \\
\hline & Max. & 0.6 & 0.06 & 4.5 & 7.9 & 2.7 & 0.2 \\
\hline \multirow{2}{*}{ St2 } & Min. & 0.1 & 0.01 & 0.7 & 7.5 & 7.5 & 0.1 \\
\hline & Max. & 0.2 & 0.06 & 7.0 & 9.5 & 9.5 & 0.2 \\
\hline \multirow{2}{*}{ St3 } & Min. & 0.2 & 0.02 & 1.6 & 7.7 & 1.2 & 0.2 \\
\hline & Max. & 2.7 & 0.1 & 6.0 & 9.5 & 13.0 & 0.4 \\
\hline \multirow{2}{*}{ St4 } & Min. & 0.9 & 0.02 & 3.0 & 7.9 & 0.4 & 0.0 \\
\hline & Max. & 2.0 & 0.1 & 10.0 & 8.2 & 14 & 0.4 \\
\hline \multirow{2}{*}{ St5 } & Min. & 1.2 & 0.02 & 0.7 & 8.0 & 0.8 & 0.2 \\
\hline & Max. & 1.6 & 0.3 & 11.0 & 9.2 & 8.0 & 0.3 \\
\hline \multirow{2}{*}{ St6 } & Min. & 0.2 & 0.02 & 0.7 & 6.6 & 0.9 & 0.2 \\
\hline & Max. & 3.4 & 0.09 & 10.0 & 7.2 & 15 & 0.3 \\
\hline \multirow{2}{*}{ St7 } & Min. & 0.4 & 0.02 & 0.7 & 8.1 & 0.9 & 0.1 \\
\hline & Max. & 1.6 & 0.05 & 7.0 & 9.4 & 5.0 & 0.5 \\
\hline \multirow{2}{*}{ St8 } & Min. & 0.4 & 0.02 & 1.5 & 7.7 & 2.0 & 0.1 \\
\hline & Max. & 1.6 & 0.05 & 4.5 & 9.3 & 4.0 & 0.2 \\
\hline
\end{tabular}

\section{Material and Methods}

\subsection{The Model}

In this work is used a coupled $3 D$ hydrodynamic/eutrophication model, Mike3 from the Danish Hydraulic Institute (DHI), as presented in [53,54]. It includes a hydrodynamic model that solves the three-dimensional incompressible Reynolds averaged Navier-Stokes equations, assuming the Boussinesq and hydrostatic pressure approximations and the general transport-diffusion equations applied to the water temperature, $T$, the salinity, $S$, and a given scalar quantity, C. This is coupled to eutrophication and water quality modules that simulate the biogeochemistry status of the lagoon, namely the phytoplankton and the macroalgae, as well as the nutrient cycles (nitrogen, $N$, and phosphorus, $P$ ) and dissolved oxygen (DO). Furthermore, it also includes rooted vegetation and a zooplankton compartment. The model also includes biogeochemistry processes occurring in the upper sediment surface layer, exchanging nutrients $(N$ and $P)$ at the interface between the water column and the upper layer of the bed sediments. The model is represented by four functional groups (phytoplankton, zooplankton, benthic vegetation, and detritus), including the nutrients and oxygen budgets, and simulates the following states variables: phytoplankton, chlorophyll-a, zooplankton, organic matter (detritus), organic and inorganic nutrients (integrating the nutrient cycling in the water column), dissolved oxygen, the turbidity of the water column (expressed as a water depth, in general, named Secchi depth), area-based biomass of benthic vegetation, as well as primary production. Although the model encompasses the diagenesis processes, namely, the mineralization of organic matter in the sediment layer, the ammonia oxidation (nitrification), and the sediment oxygen consumption, the main parameters related to these processes were not shown to significantly affect the biogeochemistry status of the water column, at least from the short and medium time scale (1-6 months). Furthermore, the model does not include suspended sediment dynamics of the water column, namely erosion and deposition processes, which result from the interaction between the sediment layer and the water column. The water turbidity, represented by the Secchi depth (representing the water transparency), includes organic matter and detritus, inorganic matter, and suspended sediments (inputted from the boundaries), reflecting, therefore, the biogeochemistry processes of the water column. The model does not simulate zooplankton, which is not assumed as a state variable, but rather as a parameter of the phytoplankton processes (through the phytoplankton grazing). The oxygen balance is an important issue, as it reflects the biogeochemistry processes within the water column, namely primary production by the phytoplankton, mineralization of organic 
matter in water and sediment, the ammonia oxidation (nitrification), and the respiration of zooplankton and phytoplankton and the exchanges with the sediment layer. Oxygen is as well exchanged with the atmosphere between the water/air interface, i.e., reaeration.

The mathematical formulations of the biological and chemical processes and transformations for each state variable are described by first-order ordinary and coupled differential equations that represent the mass balance within the water column and the sediment layer. Figure 2 summarizes the conceptual diagram of the eutrophication model.

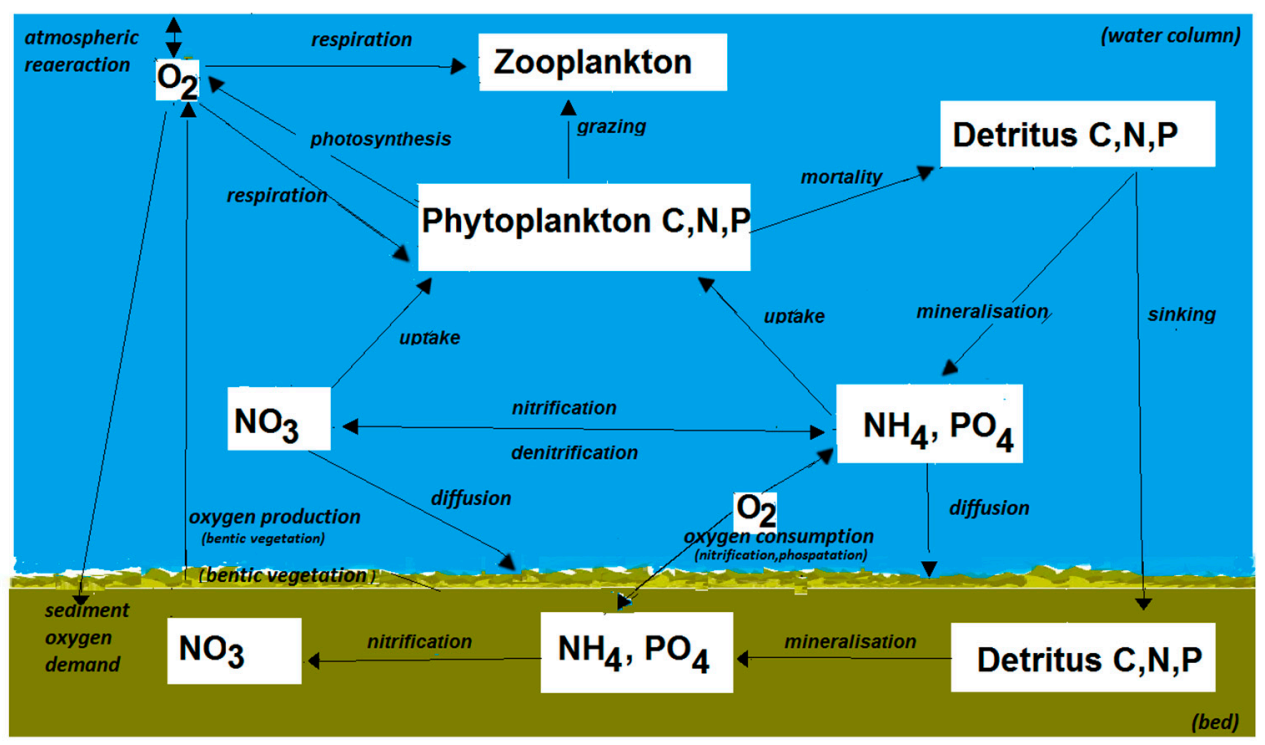

Figure 2. The conceptual diagram for the biogeochemistry model.

\subsection{The Baseline Situation and the Definition of the Scenarios}

Tides were imposed at the lagoon mouth (Barra) on the ocean open boundary using the Admiralty method of the Mike3 tide prediction of height, and the recent harmonic constants for the Barra station obtained for 2012/13 for the $\mathrm{M}_{2}$ and $\mathrm{M}_{4}$ tidal constituents [53], while the remaining constants were kept unchanged from [41-43]. Mean river inflows were imposed at the river open boundaries following results presented in Table 3 defined following Section 2. The initial and boundary conditions for physical and biogeochemistry state variables were set according to data [47-51]. The interaction with the atmosphere is allowed at the surface through the exchange of momentum, heat, and radiation. Therefore, wind speed and velocity, air temperature humidity, incident radiation, and sky clearness were imposed according to the same data.

All the scenario simulations were performed imposing a sea-level rise of $1 \mathrm{~m}$, considering a future warmer climate $\left(+2{ }^{\circ} \mathrm{C}\right)$, as discussed in [40]. The baseline situation (BS) was defined as the main simulation representing a typically dry summer case, with mean values for the river discharges adapted accordingly, as defined in Section 2. The scenarios defined represent extreme weather cases, corresponding to, respectively, the setup of dry and wet conditions in the coastal area (SC1 and SC2). These situations are likely to occur in the Aveiro coastal area in a future climate scenario, under which the river flows may experience significant changes from the baseline, as presented in Table 3. SC1 represents a future climate scenario corresponding to a dryer summer case compared to BS and, consequently, a low limit for the river's inflow regime $(20 \%$ of the reference values adopted in BS). SC2 corresponds to a wet summer case scenario, where the river discharges were set to a high limit of the mean river flow. For instance, the Vouga River flow was set to $150 \mathrm{~m}^{3} \mathrm{~s}^{-1}\left(50 \mathrm{~m}^{3} \mathrm{~s}^{-1}\right.$ for BS), considering the range of values for the mean freshwater discharges $[41,46]$. It should be noted that the extremely high values of salinity observed in summer (>30 PSU) at all sampling stations (Table 1) is clear evidence that extremely low values of river flow can be reached in this season. Furthermore, measurements of the river 
flow under extreme rainfall situations have not yet been realized. In both scenarios, the initial and the boundary conditions values for the biogeochemistry state variables were unchanged relatively to BS.

Table 3. The scenario description, combining the effects of SLR and the Vouga River discharge values.

\begin{tabular}{ccccc}
\hline Scenarios & & $\begin{array}{c}\Delta \text { T(air) } \\
\left({ }^{\circ} \mathbf{C}\right)\end{array}$ & $\begin{array}{c}\text { SLR } \\
(\mathbf{m})\end{array}$ & $\begin{array}{c}\text { River Discharge }\left(\mathbf{m}^{\mathbf{3}} \mathbf{s}^{-\mathbf{1}}\right) / \\
\text { Salinity (PSU) }\end{array}$ \\
\hline BS & Min. & 2 & +1 & $50 / 0$ \\
SC1 & Min. & 2 & +1 & $150 / 0$ \\
SC2 & Min. & 2 & +1 & $10 / 0$ \\
\hline
\end{tabular}

Each scenario, SC1/SC2, was compared to the baseline (BS) by computing the differences between the respective time series:

$$
\Delta f=f-f r
$$

where $f$ and $f r$ represent, respectively, the scenario simulation (SC1 or SC2) and the reference or the baseline simulation (BS) for each state variable (salinity, temperature, etc.). Furthermore, Taylor diagrams [55] by graphically displaying the main statistical metrics were used to quantitatively and qualitatively assess the changes induced by each scenario relative to the reference situation, the baseline simulation. The diagram is constructed by defining:

$$
\begin{gathered}
R=\frac{\frac{1}{N} \sum_{n=1}^{N}\left(f_{n}-\bar{f}\right)\left(f r_{n}-\overline{f r}\right)}{\sigma_{f} \sigma_{r}} \\
R M S D^{2}=\frac{1}{N} \sum_{n=1}^{N}\left\{\left(f_{n}-\bar{f}\right)\left(f r_{n}-\overline{f r}\right)\right\}^{2} \\
\sigma_{f}^{2}=\frac{1}{N} \sum_{n=1}^{N}\left(f_{n}-\bar{f}\right)^{2} \\
\sigma_{r}^{2}=\frac{1}{N} \sum_{n=1}^{N}\left(f r_{n}-\overline{f r}\right)^{2}
\end{gathered}
$$

where $R$ and RMSD represent, respectively, the Pearson correlation coefficient and the centered root mean square deviation between the simulation and the baseline/reference time series. $n$ is the number of points in the time series, and $\sigma_{f}$ and $\sigma_{r}$ the standard deviations of the simulation field and the baseline/reference field, respectively.

\section{Results}

This section presents the results for the scenarios previously defined, addressing the influence of extreme situations induced by climate changes on the lagoon ecosystem. Henceforth, BS corresponds to the baseline simulation and SC1 and SC2 to the scenarios defined and simulated.

\subsection{The Baseline/Reference Situation (BS) and the Dry Summer Scenario (SC1)}

Figures 3 and 4 present, respectively, salinity time series for the baseline (BS) and for each scenario (SC1 and SC2) and $\Delta$ (salinity) time series representing the differences between the baseline (BS) and each scenario SC1 and SC2. Table 4 presents the statistic metrics for $\Delta$ (salinity) (maximum-minimum, mean values, and standard deviation), representing the difference between the two time series for BS and SC1/SC2 (Equation (1)). 


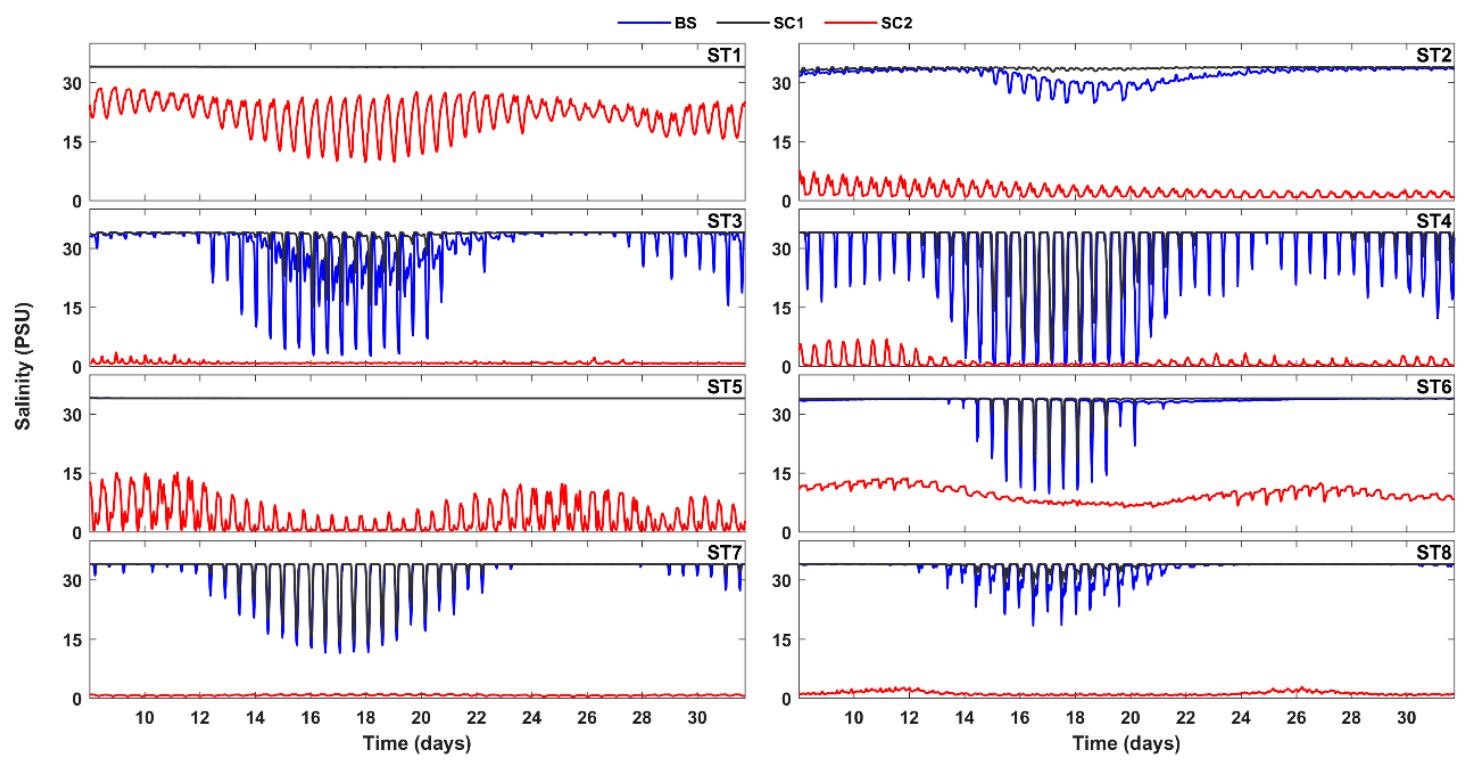

Figure 3. Salinity time series for the baseline (BS) and the scenarios SC1 and SC2 for all the lagoon stations under analysis (St1-St8).
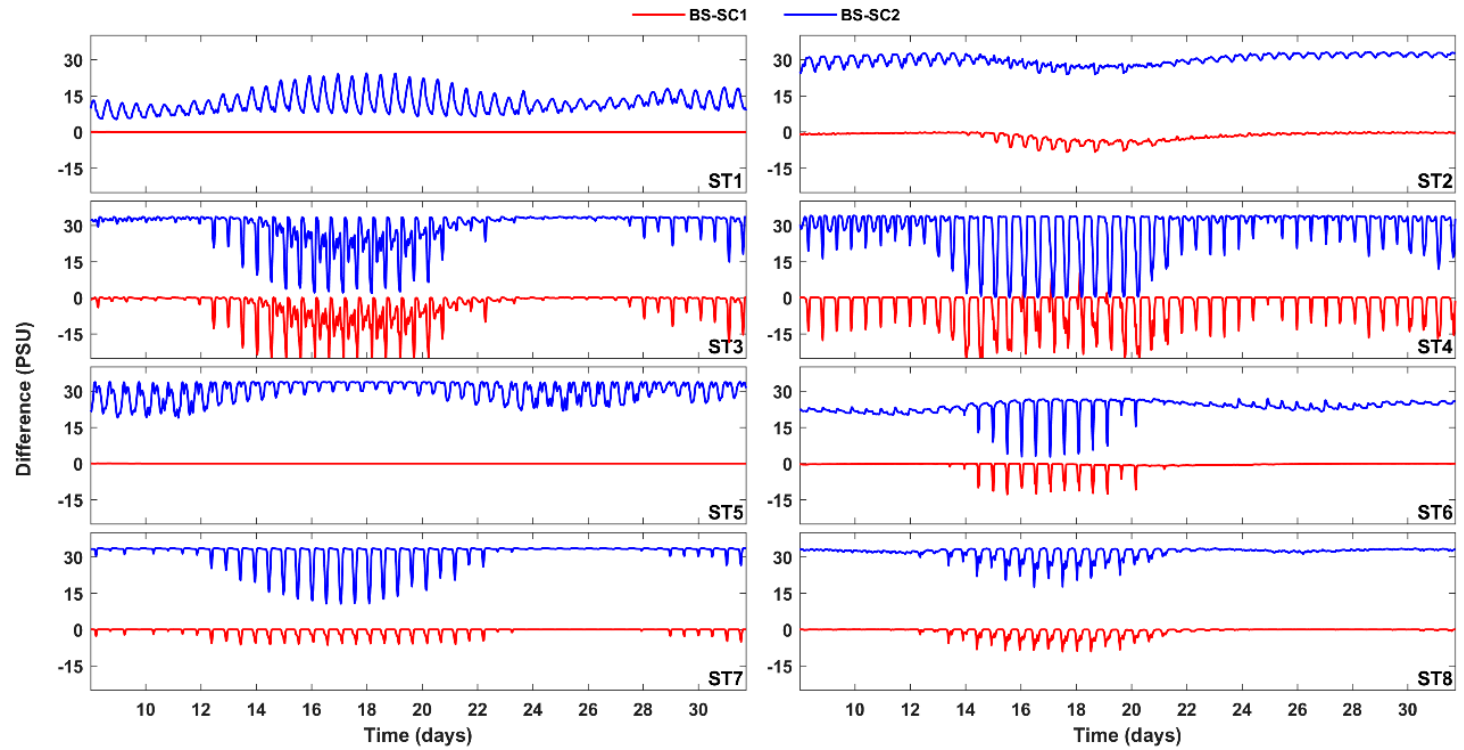

Figure 4. $\Delta$ (Salinity) time series for the differences between the baseline (BS) and each scenario SC1 and SC2 for all the lagoon stations under analysis (St1-St8).

BS time series evolution (Figure 3, blue lines) depends on the tidal cycle, a semi-diurnal oscillation, with strong fortnight modulation. It can be observed that salinity covers a wide range of values (5-34 PSU) at the stations located on the river areas and heads of the channels (Sts. 3, 4, 6, 7, and 8), namely during the spring tide period (between day 12 and day 23). This corresponds to significant salinity oscillation, reflecting the competition between the river and the ocean waters influence at those areas: the river flow influence extends toward the central lagoon areas during the ebb, while during the flood, the ocean water penetrates deep into these areas. St1 is typically an ocean station, exhibiting high salinity values ( $\sim 34$ PSU). St2, although situated near the lagoon mouth and, therefore, under the dominant influence of the ocean water, exhibits a mix-water pattern with a significant salinity range ( 25-34 PSU). This feature results from its location close to the Espinheiro Channel, and therefore under the influence of the Vouga River. St5 presents, as well, typical values for the ocean waters ( 34 PSU), reflecting the influence of the ocean 
even in the central areas of the lagoon. Indeed, this station is situated in the middle of the S. Jacinto Channel (see Figure 1), under the influence of an important tidal prism flowing along this channel [41]. This results in a strong oscillation of the salinity values observed during the spring tide, ranging between two extreme values (5-34 PSU) when the ocean and the freshwater flow converge in the central areas.

Table 4. $\Delta$ (Salinity) metrics for BS/SC1 and BS/SC2 for the lagoon stations (St1-St8).

\begin{tabular}{cccccc}
\hline Stations & Scenarios & $\begin{array}{c}\text { Minimum } \\
\text { (PSU) }\end{array}$ & $\begin{array}{c}\text { Maximum } \\
\text { (PSU) }\end{array}$ & $\begin{array}{c}\text { Average } \\
\text { (PSU) }\end{array}$ & $\begin{array}{c}\text { Standard } \\
\text { Deviation } \\
\text { (PSU) }\end{array}$ \\
\hline \multirow{2}{*}{ St1 } & BS-SC1 & 0.0 & 0.1 & 0.0 & 0.0 \\
& BS-SC2 & -5.8 & -24.3 & -12.4 & 4.0 \\
St2 & BS-SC1 & -1.2 & 0.3 & -0.2 & 0.2 \\
& BS-SC2 & -23.8 & -33.0 & -30.0 & 2.2 \\
St3 & BS-SC1 & -19.0 & 0.0 & -0.6 & 2.2 \\
& BS-SC2 & -2.0 & -33.5 & -29.3 & 6.9 \\
St4 & BS-SC1 & -25.8 & 0.0 & -1.5 & 4.9 \\
& BS-SC2 & -0.2 & -33.9 & -28.7 & 8.8 \\
St5 & BS-SC1 & -0.0 & 0.0 & 0.0 & 0.0 \\
& BS-SC2 & -18.9 & -33.8 & -30.5 & 3.6 \\
St6 & BS-SC1 & -15.2 & -0.0 & -0.3 & 1.5 \\
& BS-SC2 & -2.7 & -27.0 & -23.6 & 3.2 \\
St7 & BS-SC1 & -9.9 & 0.0 & -1.0 & 3.3 \\
& BS-SC2 & -10.60 & -33.6 & -31.8 & 4.3 \\
St8 & BS-SC1 & -7.6 & 0.0 & -0.2 & 0.7 \\
& BS-SC2 & -17.5 & -33.5 & -31.9 & 2.1 \\
\hline
\end{tabular}

The dry scenario, SC1, evidences a lagoon almost infilled with ocean water, as the salinity present values close to 34 PSU, except at the stations located on the river areas and heads of the channels, where similarly to BS, significant salinity oscillation are observed during the spring tide. These patterns are reflected in the snapshots of the horizontal salinity distribution represented in Figure 5, for both BS (a0,b0) and SC1 (a1,b1), representing, respectively, the neap/high tide at the mouth $(\mathrm{a} 0, \mathrm{~b} 0)$ and the spring/low tide at the lagoon mouth $(\mathrm{a} 1, \mathrm{~b} 1)$. These salinity distribution maps confirm that under the dry scenario, SC1, the lagoon is mostly under the influence of the ocean waters ( 34 PSU), with the salinity intrusion penetrating far ahead until the head of each of the main channels.

Figures 6 and 7 present, respectively, the water temperature and $\Delta$ (temperature) time series for BS and SC1. Again, it can be observed that the two simulations show similar values, although SC1 presents slightly lower values. The water temperature time evolution presents mainly a typical diurnal pattern, with the values varying within the range of 18-22 ${ }^{\circ} \mathrm{C}$, as observed in Table 5. St1, which is situated closer to the ocean boundary, shows the lowest temperature value, as well as the smallest range of variation, $18.5-19.6{ }^{\circ} \mathrm{C}$, reflecting an ocean water characteristic. The shallow stations situated at the river areas and heads of the channels show the highest water temperatures, within a relatively wide range of variation, $19-21^{\circ} \mathrm{C}$. $\Delta$ (Temperature) (Figure 7 and Table 5) shows positive values, reaching maximum values up to $1^{\circ} \mathrm{C}$, corresponding to a water temperature decrease from SC1 to BS (red lines). Compared to salinity, the small-amplitude range of variations of the water temperature for $\Delta$ (temperature) reflects the influence of the inertia of the water to the heat exchanges, of the daily solar heating, and the ocean water. Indeed, Figure $8(\mathrm{a} 0, \mathrm{~b} 0)$ snapshots, representing the water temperature horizontal distributions for BS, depict the spread of the ocean cold water throughout the main channels as well as the front between cold water from the ocean and warm waterfront from the inner lagoon. The ocean influence is dominant during spring tide when the cold ocean water that flows throughout the main channels reaches its maximum extension (Figure $8(\mathrm{~b} 0, \mathrm{~b} 1)$ ). Furthermore, for $(\mathrm{b} 1)$ is found a higher range of water temperature $\left(23.5-24.5^{\circ} \mathrm{C}\right)$ compared to $(\mathrm{b} 0)\left(22.8^{\circ} \mathrm{C}\right)$, evidencing that the warm water flow from the upper head of the lagoon is enhanced during ebb flow. 

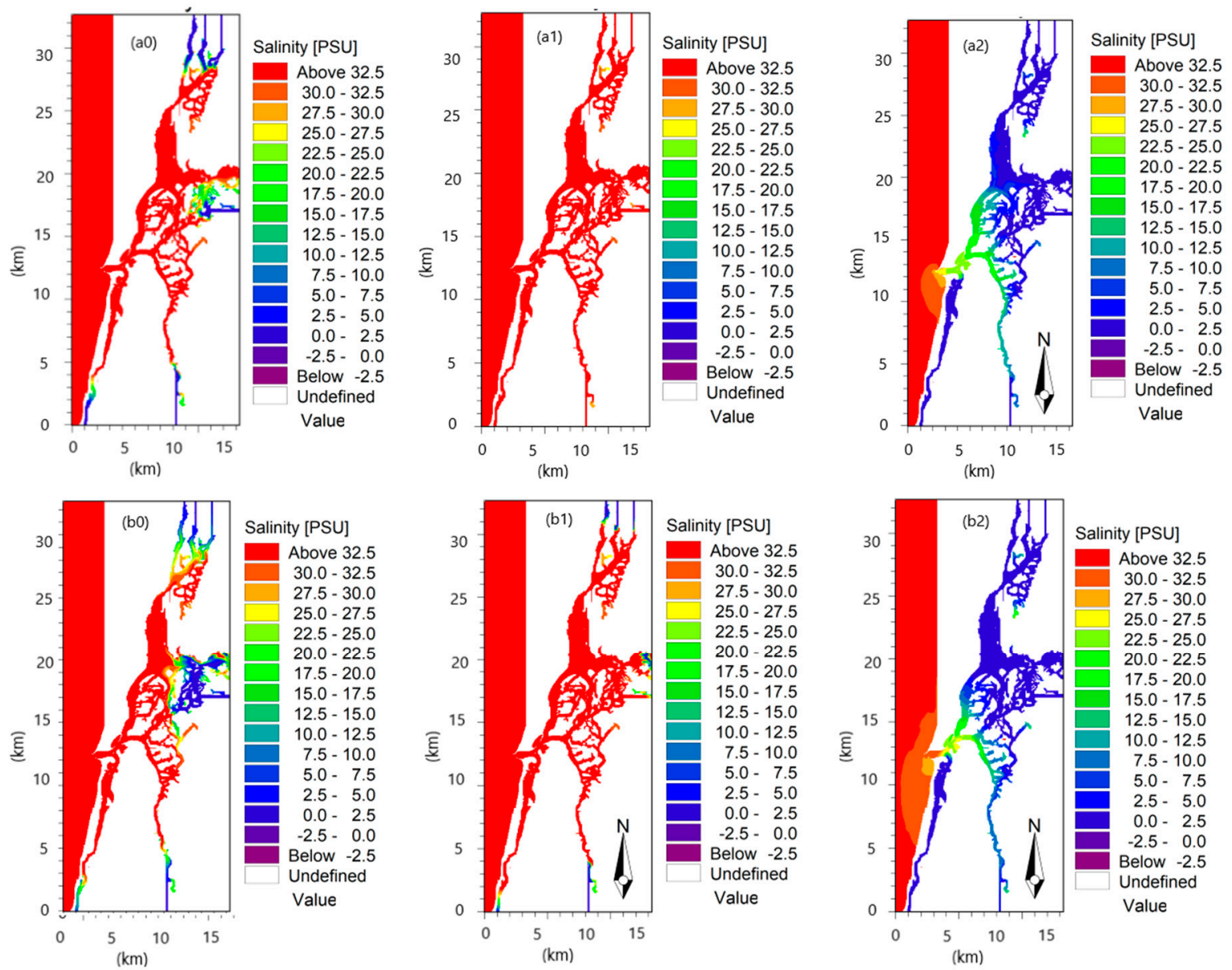

Figure 5. Salinity (PSU) snapshots for BS (a0,b0), SC1 (a1,b1), and SC2 (a2,b2), for two instants: (a)-neap/high tide at the lagoon mouth (day 25); (b)-spring/low tide at the lagoon mouth (day 16).

Table 5. $\Delta$ (Temperature) metrics for BS/SC1 and BS/SC2 for the lagoon Stations (St1-St8).

\begin{tabular}{|c|c|c|c|c|c|}
\hline Stations & Scenarios & $\begin{array}{c}\text { Minimum } \\
\left({ }^{\circ} \mathrm{C}\right)\end{array}$ & $\begin{array}{l}\text { Maximum } \\
\quad\left({ }^{\circ} \mathrm{C}\right)\end{array}$ & $\begin{array}{c}\text { Average } \\
\left({ }^{\circ} \mathrm{C}\right)\end{array}$ & $\begin{array}{c}\text { Standard } \\
\text { Deviation } \\
\left({ }^{\circ} \mathrm{C}\right)\end{array}$ \\
\hline \multirow[t]{2}{*}{ St1 } & BS-SC1 & -0.72 & 0.26 & -0.27 & 0.16 \\
\hline & BS-SC2 & -2.44 & 0.31 & -1.22 & 0.59 \\
\hline \multirow[t]{2}{*}{ St2 } & BS-SC1 & -1.82 & 0.60 & -0.60 & 0.240 \\
\hline & BS-SC2 & -1.18 & 1.73 & 0.39 & 0.55 \\
\hline \multirow[t]{2}{*}{ St3 } & BS-SC1 & -2.00 & 0.21 & -0.66 & 0.40 \\
\hline & BS-SC2 & -2.19 & 1.28 & -0.18 & 0.55 \\
\hline \multirow[t]{2}{*}{ St4 } & BS-SC1 & -2.00 & 0.00 & -1.51 & 4.93 \\
\hline & BS-SC2 & -3.17 & 1.55 & -0.47 & 0.50 \\
\hline \multirow[t]{2}{*}{ St5 } & BS-SC1 & -1.13 & 0.41 & -0.30 & 0.22 \\
\hline & BS-SC2 & -3.42 & 0.54 & -1.55 & 0.92 \\
\hline \multirow[t]{2}{*}{ St6 } & BS-SC1 & -1.22 & -0.01 & -0.70 & 0.21 \\
\hline & BS-SC2 & -0.63 & 1.50 & 0.45 & 0.39 \\
\hline \multirow[t]{2}{*}{ St7 } & BS-SC1 & -1.30 & 0.35 & -0.42 & 0.27 \\
\hline & BS-SC2 & -2.77 & 0.92 & -0.61 & 0.68 \\
\hline \multirow[t]{2}{*}{ St8 } & BS-SC1 & -2.00 & 0.0526 & -0.280 & 0.41 \\
\hline & BS-SC2 & -0.92 & 1.40 & 0.240 & 0.50 \\
\hline
\end{tabular}




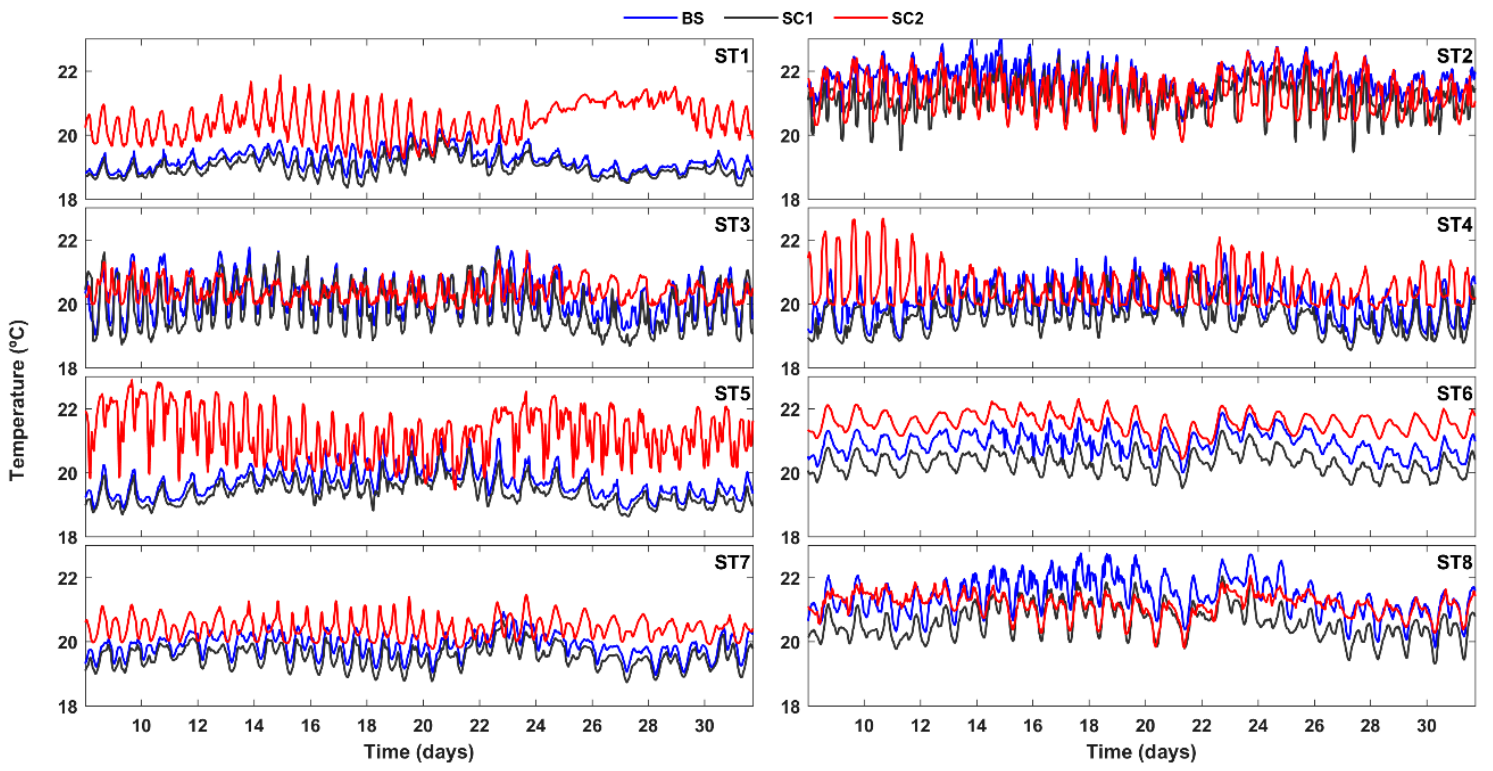

Figure 6. Water temperature time series for the baseline (BS) and the scenarios SC1 and SC2 for all the lagoon stations under analysis (St1-St8).
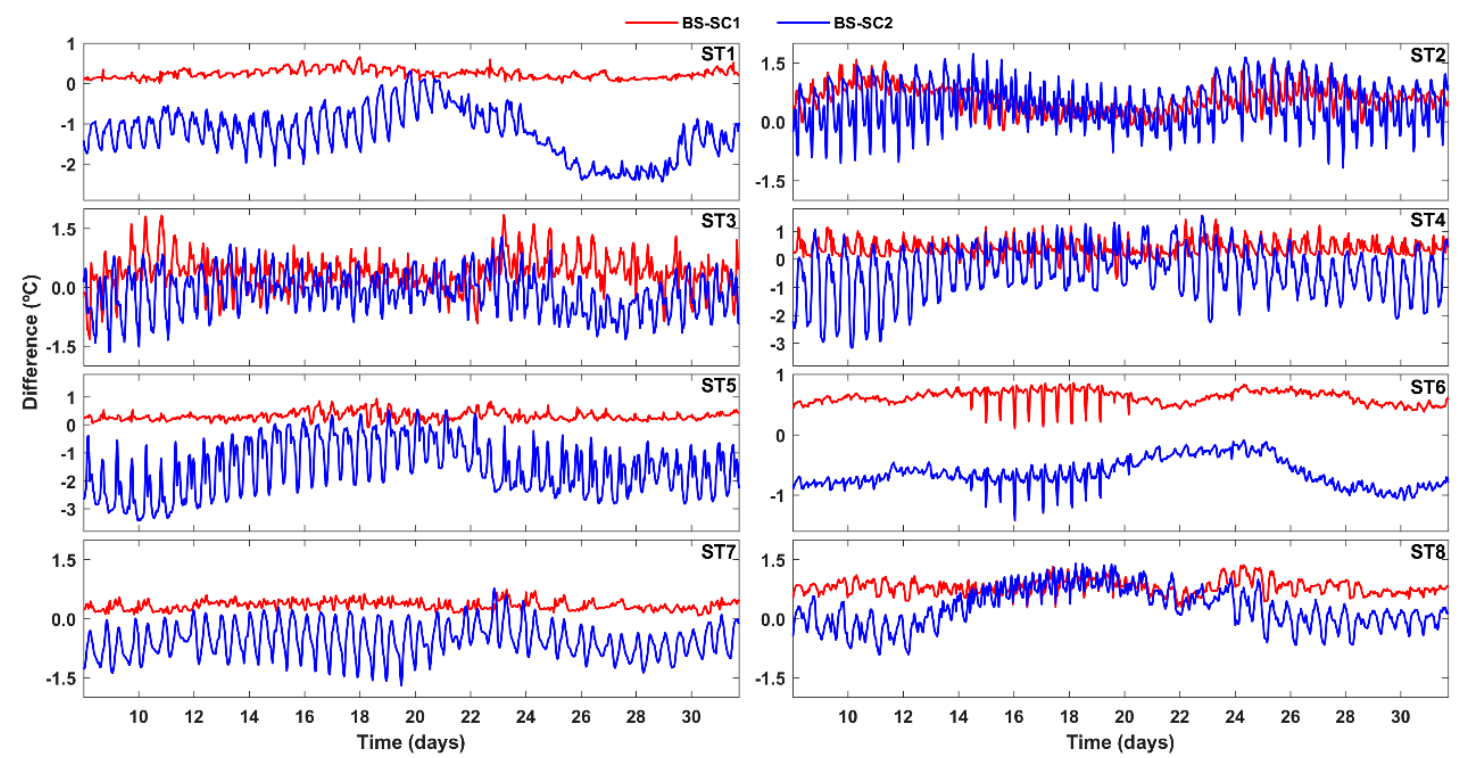

Figure 7. $\Delta$ (Temperature) time series for the differences between the baseline (BS) and each scenario SC1 and SC2 for all the lagoon stations under analysis (St1-St8). 

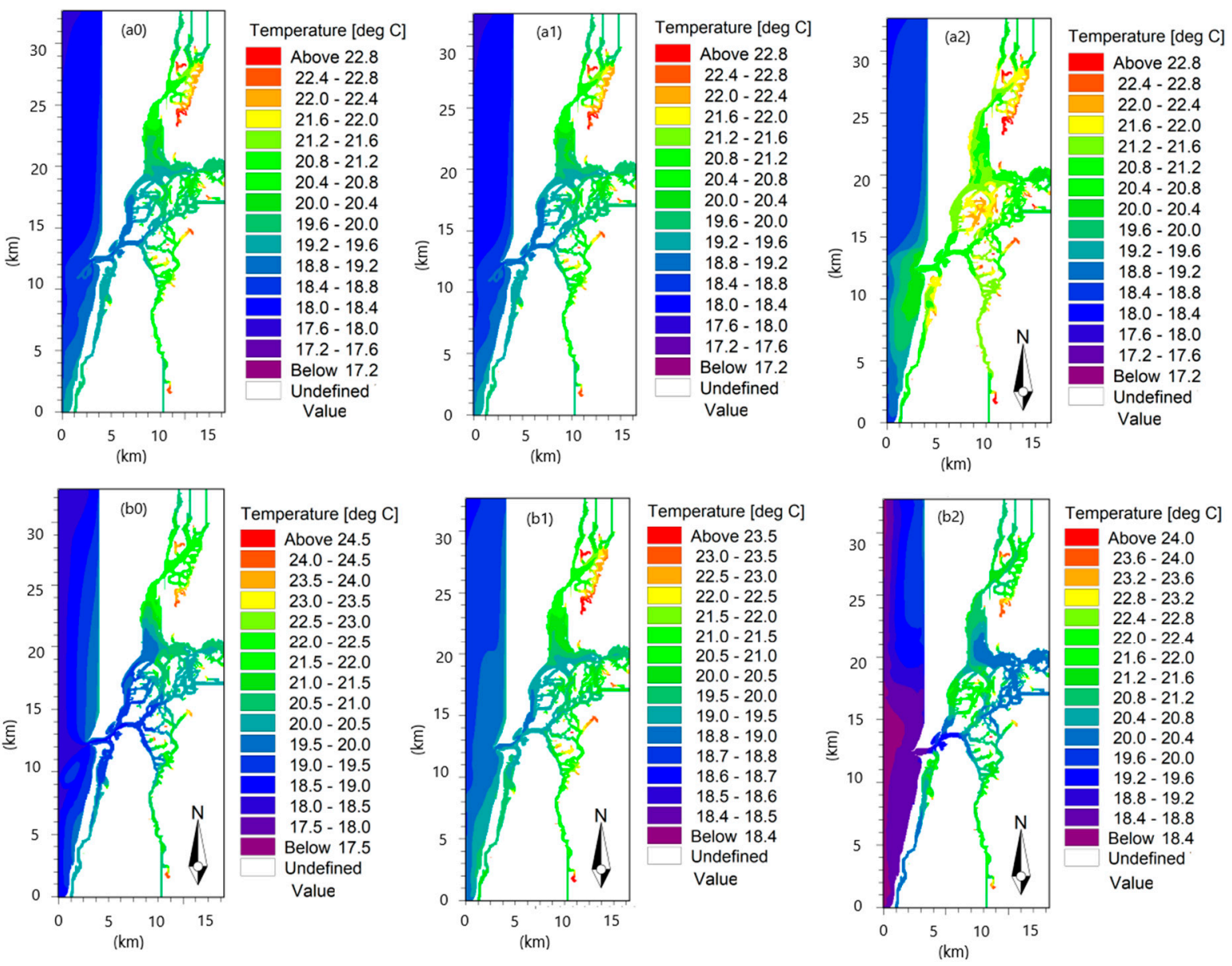

Figure 8. Water temperature $\left({ }^{\circ} \mathrm{C}\right)$ snapshots for BS (a0,b0), SC1 (a1,b1), and SC2 (a2,b2), for two instants: (a)-neap/high tide at the lagoon mouth (day 25); (b)-spring/low tide at the lagoon mouth (day 16).

The next figures present time series for the biogeochemistry variables, as well as $\Delta(\mathrm{V})$ between the baseline (BS) and each scenario: the inorganic $N(\mathrm{IN})$, the phytoplankton carbon (PC), and the dissolved oxygen (DO).

Figure 9 presents IN time series for BS and SC1. It can be observed that both show quite similar values and variability, which is semi-diurnal with a fortnight modulation. The concentration values vary within the range of $0.5-2 \mathrm{mg} \mathrm{L}^{-1}$, which are typical for the lagoon as presented in Table 2, reflecting, respectively, the influence of the river and the ocean waters. As expected, the stations located at river areas and heads of the channels show high concentration values $\left(\sim 2 \mathrm{mg} \mathrm{L}^{-1}\right)$, while the higher values are observed in St5 $\left(\sim 1 \mathrm{mg} \mathrm{L}^{-1}\right)$, reflecting its location, as previously referred. On the other hand, St1 and St 5 show the lowest concentration values $\left(<0.5 \mathrm{mg} \mathrm{L}^{-1}\right)$. $\Delta$ (IN) time series for SC1 (Figure 10, red lines and Table 6) show, in general, moderate positive values $\left(\sim 0.4 \mathrm{mg} \mathrm{L}^{-1}\right)$ and small-amplitude variations, excepting for Stations 3, 4, and 6, which show higher values $\left(\sim 2 \mathrm{mg} \mathrm{L}^{-1}\right)$ during the spring-neap period, denoting an overall IN concentration decrease comparing to BS. Indeed, the snapshots of Figure 11(a1,b1) representing the IN horizontal distributions for SC1 reveal an overall reduction in the concentration inside the lagoon compared to $\mathrm{BS}(\mathrm{a} 0, \mathrm{~b} 0)$, where the maximum value falls from $\sim 2.0$ to $\sim 0.4 \mathrm{mg} \mathrm{L}^{-1}$, reflecting the reduction in the nutrient fluxes from the river boundaries. 
Table 6. $\Delta(\mathrm{IN})$ metrics for BS/SC1 and BS/SC2, and the lagoon stations (St1-St8).

\begin{tabular}{|c|c|c|c|c|c|}
\hline Stations & Scenarios & $\underset{\left(\mathrm{mg} \mathrm{L}^{-1}\right)}{\operatorname{Minimum}}$ & $\underset{\left(\mathrm{mg} \mathrm{L}^{-1}\right)}{\text { Maximum }}$ & $\begin{array}{l}\text { Average } \\
\left(\mathrm{mg} \mathrm{L}^{-1}\right)\end{array}$ & $\begin{array}{c}\text { Standard } \\
\text { Deviation } \\
\left(\mathrm{mg} \mathrm{L}^{-1}\right)\end{array}$ \\
\hline \multirow[t]{2}{*}{ St1 } & BS-SC1 & -0.2 & 0.3 & -0.1 & 0.1 \\
\hline & BS-SC2 & -3.1 & -0.6 & -1.4 & 0.4 \\
\hline \multirow[t]{2}{*}{ St2 } & BS-SC1 & 0.6 & 2.1 & 0.3 & 0.4 \\
\hline & BS-SC2 & -2.2 & 0.3 & -1.3 & 0.5 \\
\hline \multirow[t]{2}{*}{ St3 } & BS-SC1 & -0.2 & 1.7 & 0.2 & 0.3 \\
\hline & BS-SC2 & -2.6 & -0.1 & -1.5 & 0,5 \\
\hline \multirow[t]{2}{*}{ St4 } & BS-SC1 & -0.2 & 1.9 & 0.2 & 0,3 \\
\hline & BS-SC2 & -6.0 & -3.9 & -5.2 & 0.6 \\
\hline \multirow[t]{2}{*}{ St5 } & BS-SC1 & -0.2 & 0.6 & 0.1 & 0.9 \\
\hline & BS-SC2 & -6.0 & -3.5 & -5.0 & 0.6 \\
\hline \multirow[t]{2}{*}{ St6 } & BS-SC1 & -0.1 & 1.4 & 0.2 & 0.3 \\
\hline & BS-SC2 & -1.9 & -0.2 & -1.6 & 0.2 \\
\hline \multirow[t]{2}{*}{ St7 } & BS-SC1 & -0.1 & 1.1 & 0.1 & 0.2 \\
\hline & BS-SC2 & -2.0 & -0.6 & -1.7 & 0.3 \\
\hline \multirow[t]{2}{*}{ St8 } & BS-SC1 & -0.1 & 1.4 & 0.2 & 0.2 \\
\hline & BS-SC2 & -5.9 & -4.5 & -5.3 & 0.3 \\
\hline
\end{tabular}

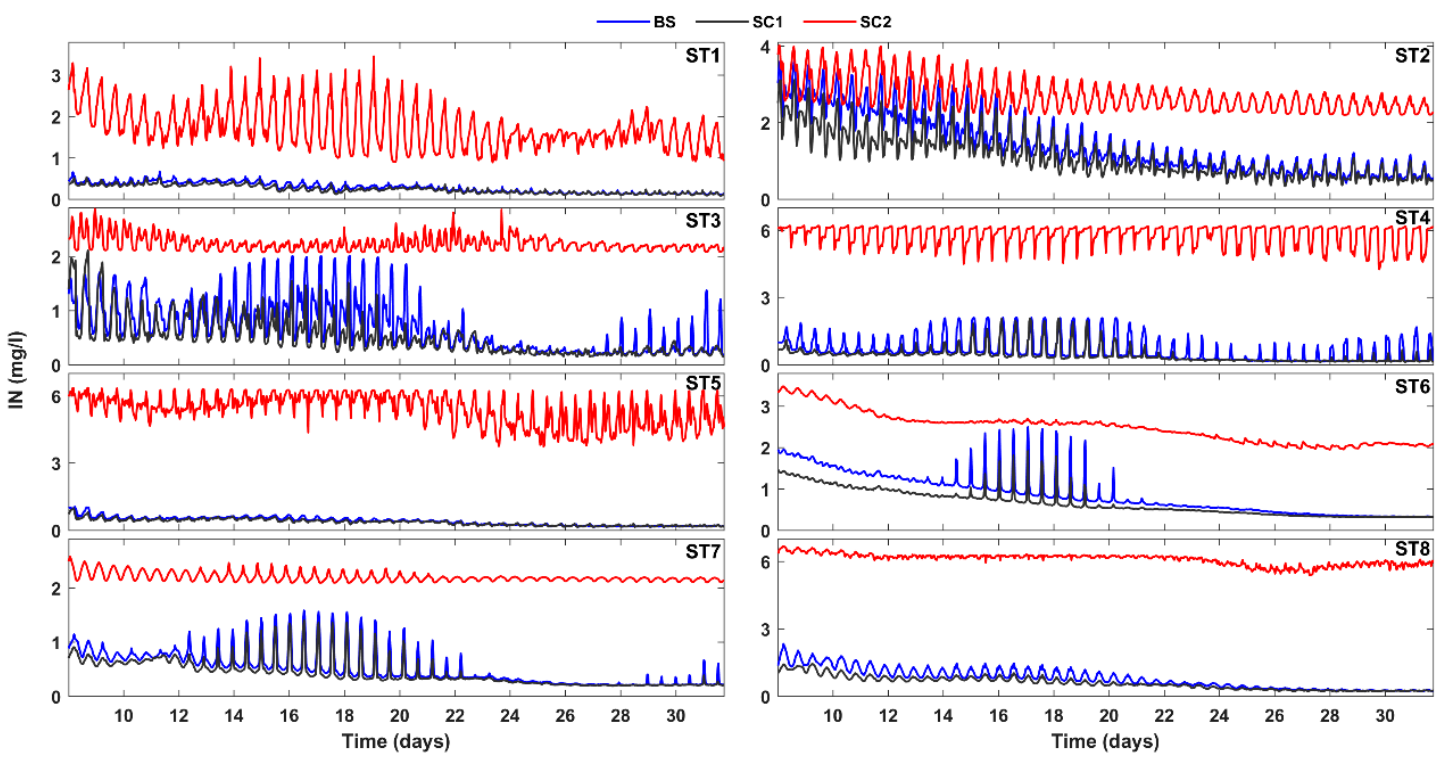

Figure 9. IN time series for the baseline (BS) and the scenarios SC1 and SC2 for all the lagoon stations under analysis (St1-St8). 

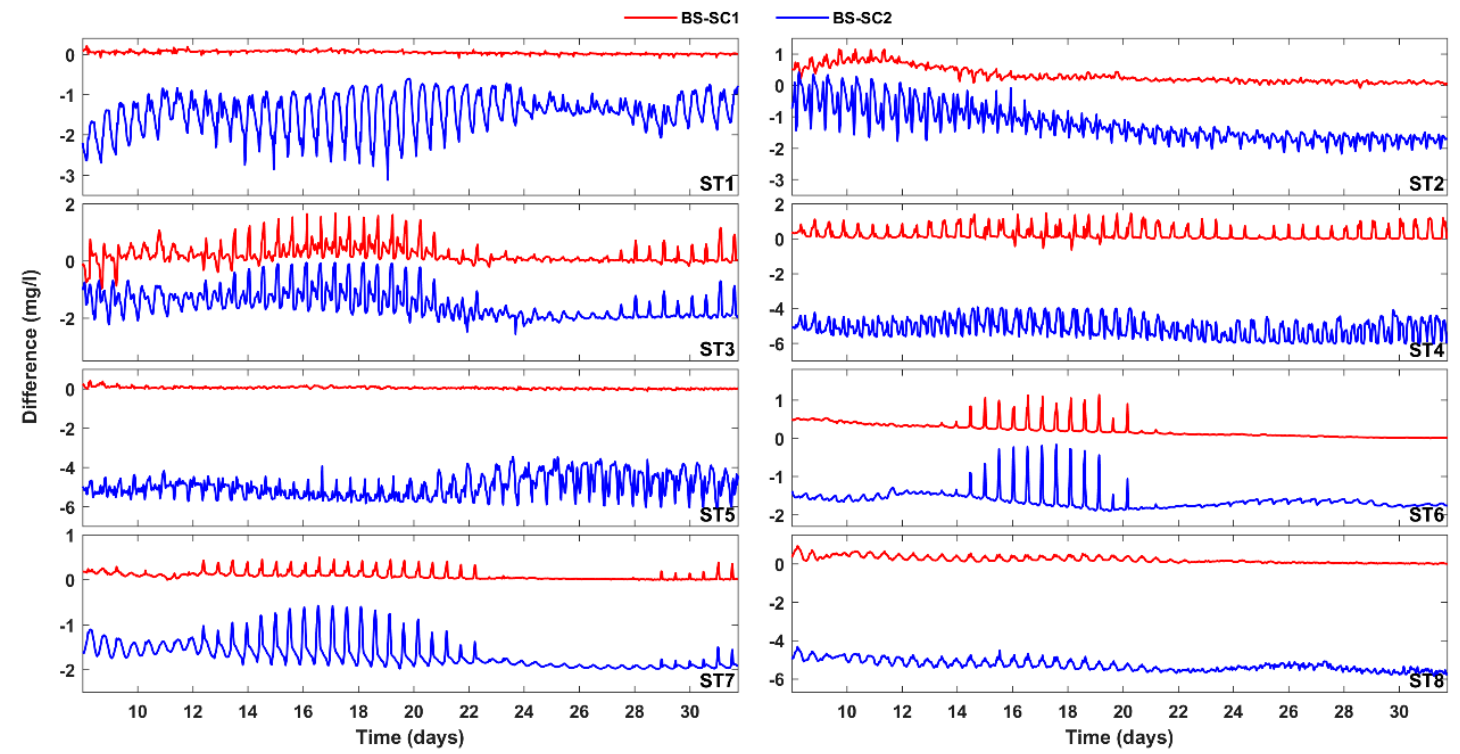

Figure 10. $\Delta(\mathrm{IN})$ time series for the differences between the baseline (BS) and each scenario SC1 and SC2 for all the lagoon stations under analysis (St1-St8).
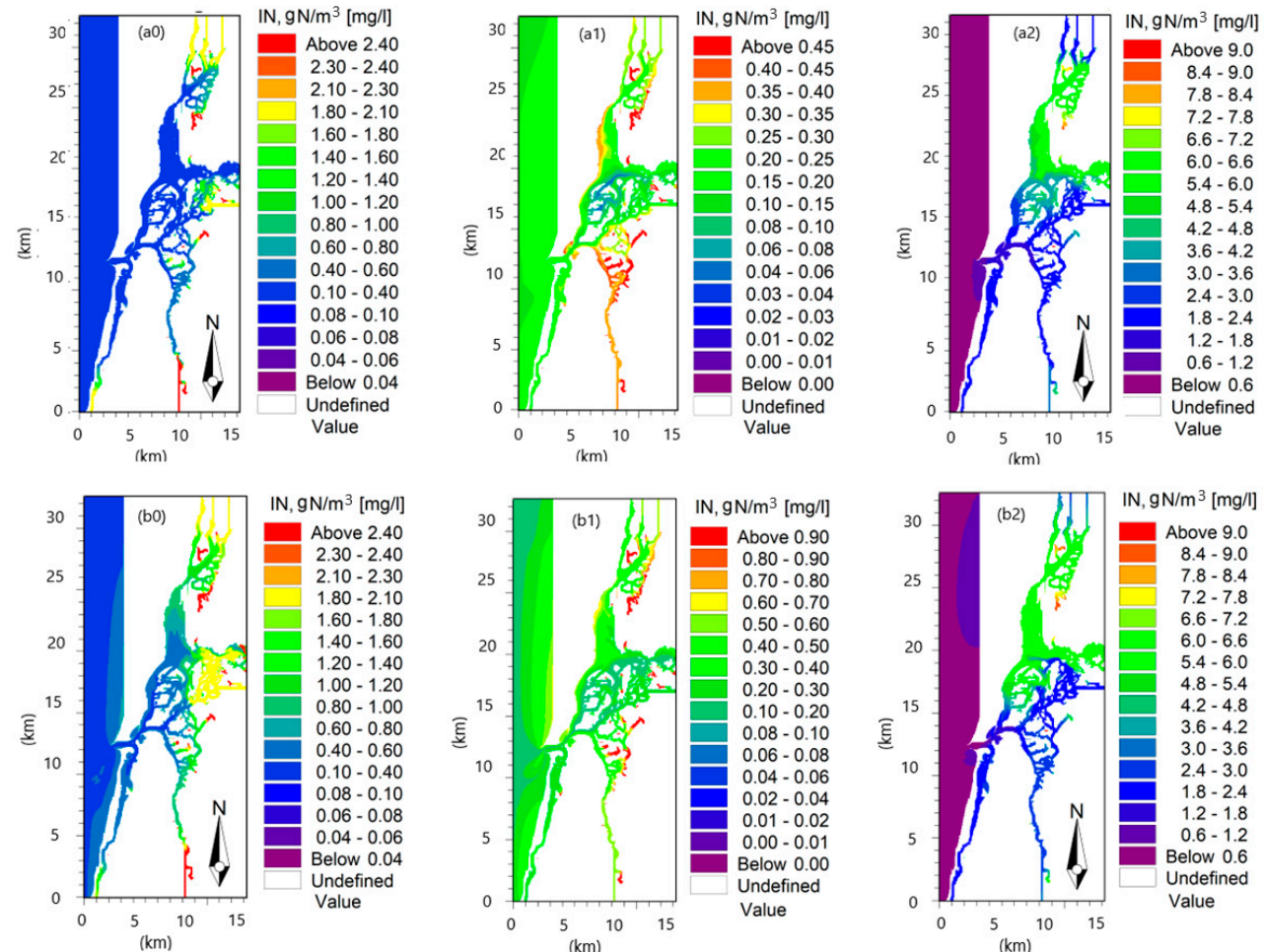

Figure 11. IN $\left(\mathrm{mg} \mathrm{L}^{-1}\right)$ snapshots for BS $(\mathbf{a} 0, \mathbf{b} 0)$, SC1 (a1,b1), and SC2 $(\mathbf{a} 2, \mathbf{b} 2)$ for two instants: $(\mathbf{a})$-neap/high tide at the lagoon mouth (day 25); (b)-spring/low tide at the lagoon mouth (day 16).

PC time series (Figure 12) for BS and SC1 depict diurnal and fortnight oscillations, reflecting that the main drivers of the phytoplankton growth are tide forcing and solar radiation. In general, the concentrations show moderate values $\left(<0.2 \mathrm{mg} \mathrm{L}^{-1}\right)$, which are typical for summer, as observed in Table 2, except for the stations at the river areas and heads of the channels or during the spring-neap tide period, where the concentration values spike to higher values $\left(\sim 0.6 \mathrm{mg} \mathrm{L}^{-1}\right)$. It is worth noting, as referred to in Section 2, that the stations under the ocean influence, namely St 1 and St5, show low concentration values $\left(<0.1 \mathrm{mg} \mathrm{L}^{-1}\right)$. Concerning SC1, $\Delta(\mathrm{PC})$ (Figure 13, red lines, and Table 7 presents 
high positive values during the spring-neap period for the stations located at the river areas and heads of the channels, namely St3 and 4, where it reaches values as high as $0.5 \mathrm{mg} \mathrm{L}^{-1}$, while low values are found for the remaining stations $\left(\sim 0.1 \mathrm{mg} \mathrm{L}^{-1}\right)$. This depicts a moderate decrease in the phytoplankton concentration in the main lagoon area but a high decrease near the river areas and heads of the channels. Figure 14 presents snapshots of PC horizontal distributions, for BS $(\mathrm{a} 0, \mathrm{~b} 0)$ and SC1 $(\mathrm{a} 1, \mathrm{~b} 1)$. For BS (b0), the maximum concentration values $\left(\sim 0.4 \mathrm{mg} \mathrm{L}^{-1}\right)$ are located at the river areas and heads of the channels, where the main spots are observed stretching toward the central lagoon area during the ebb flow $(\mathrm{b} 0)$. On the other hand, the dry scenario SC1 $(\mathrm{a} 1, \mathrm{~b} 1)$ does not present any significant concentration values, as they were reduced by more than half $\left(<0.2 \mathrm{mg} \mathrm{L}^{-1}\right)$ compared to BS, reflecting the IN shortage.

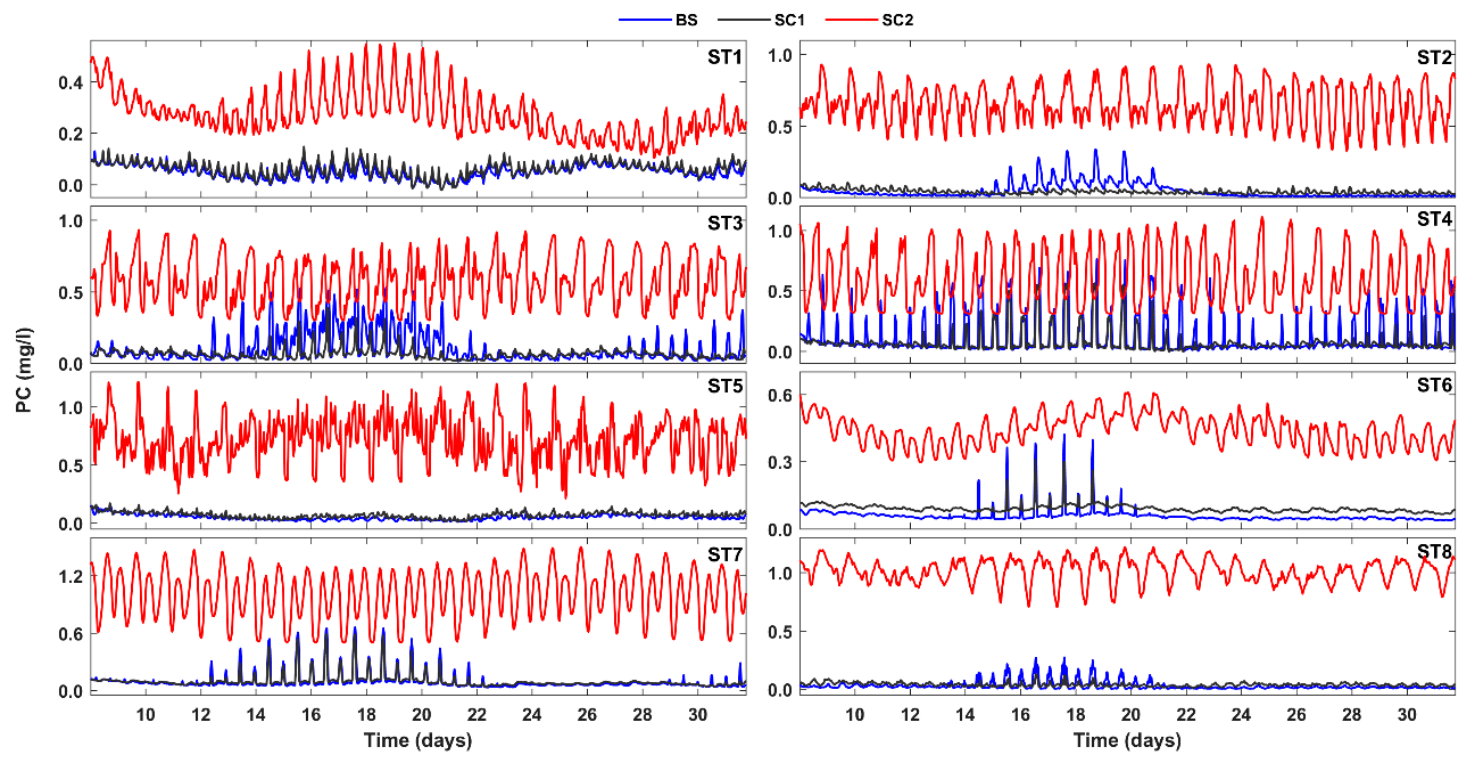

Figure 12. PC time series for the baseline (BS) and the scenarios SC1 and SC2 for all the lagoon stations under analysis (St1-St8).
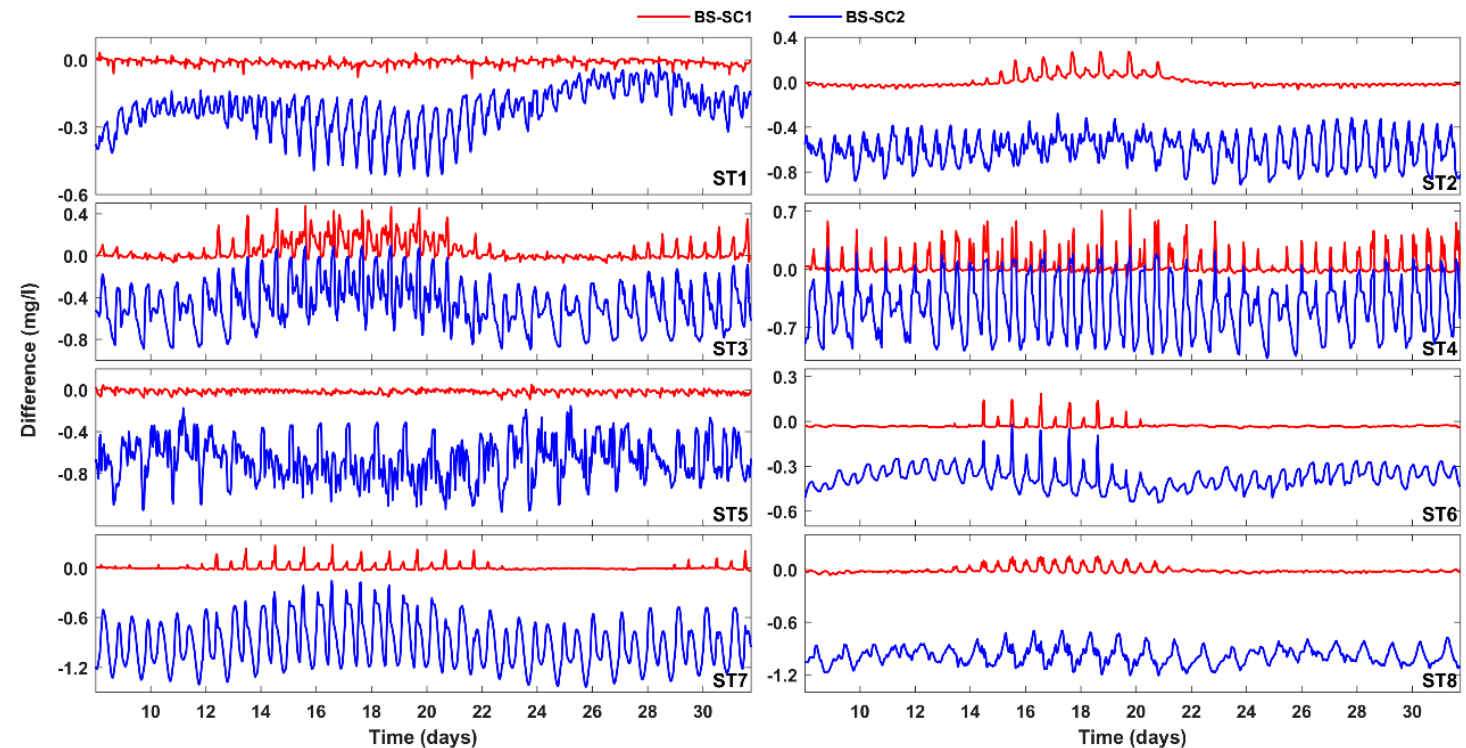

Figure 13. $\triangle(\mathrm{PC})$ time series for the differences between the baseline (BS) and each scenario SC1 and SC2 for all the lagoon stations under analysis (St1-St8). 

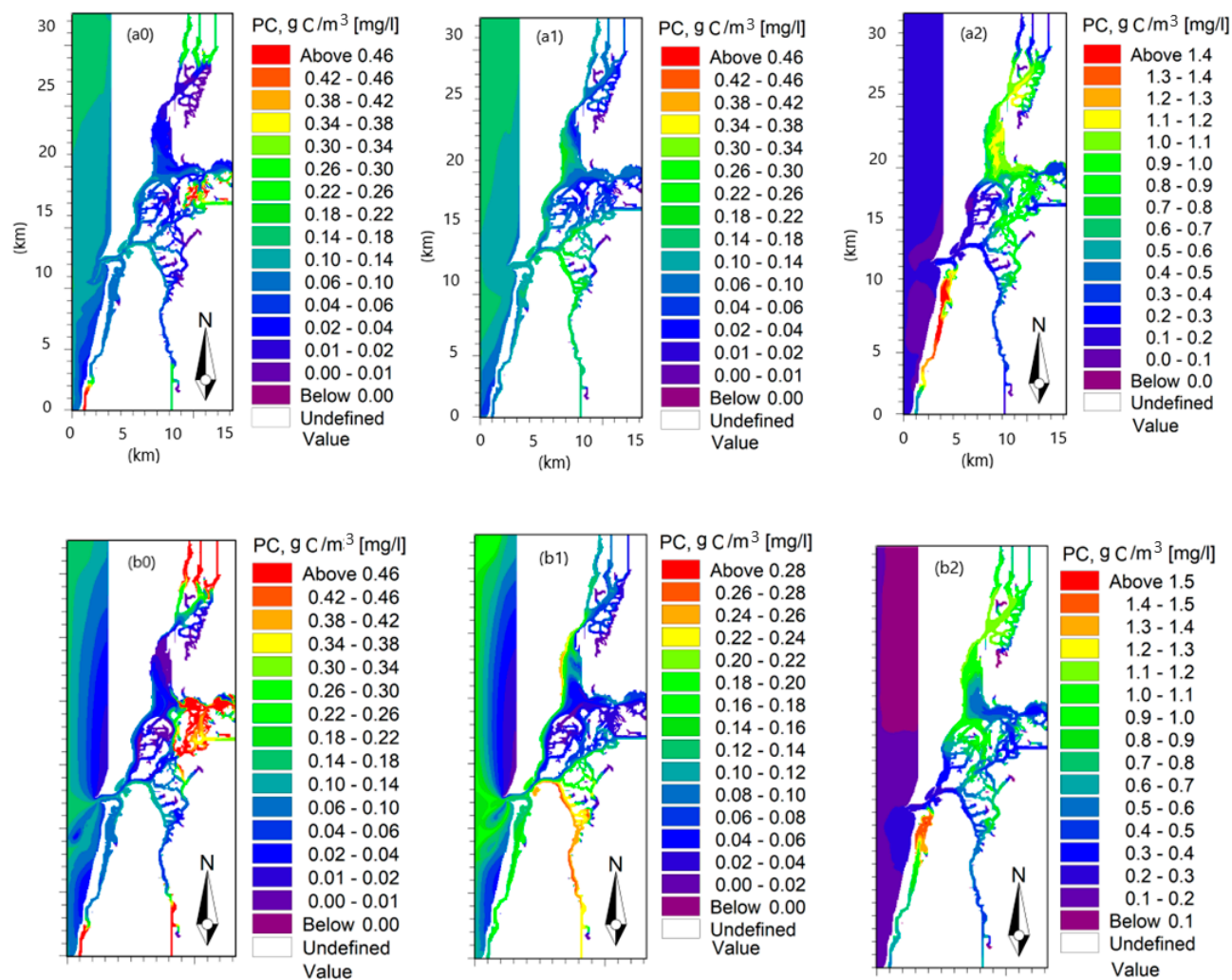

Figure 14. PC $\left(\mathrm{mg} \mathrm{L}^{-1}\right)$ snapshots for BS (a0,b0), SC1 (a1,b1), and SC2 (a2,b2) for two instants: (a)-neap/high tide at the lagoon mouth (day 25); (b)-spring/low tide at the lagoon mouth (day 16).

Figure 15 presents BS and SC1 time series for DO. As for PC, they are characterized by diurnal and semi-diurnal oscillations. Furthermore, it was not found significant springneap tide oscillations except for the stations located on the river areas and heads of the channels $(3,4$, and 6$)$. In general, the concentration values are moderate $\left(\sim 8 \mathrm{mg} \mathrm{L}^{-1}\right)$, except for the shallow area close to St 3 and during spring tide $(\mathrm{a} 0, \mathrm{~b} 0)$, where a localized hypoxia spot is observed $\left(<6 \mathrm{mg} \mathrm{L}^{-1}\right)$ near Station 3. Furthermore, Figure 16 (red lines) and Table 8 show small $\mathrm{D}(\mathrm{DO})$ values $\left(\sim 0.1 \mathrm{mg} \mathrm{L}^{-1}\right)$, representing insignificant changes between BS and SC1. Indeed, the DO snapshots horizontal distributions (Figure 17) show that the two simulations $((\mathrm{a} 0, \mathrm{~b} 0, \mathrm{a} 1, \mathrm{~b} 1))$ are quite similar, with slightly higher values for the river areas and heads of the channels. It is worth noting that the localized hypoxia $\left.\left(<6 \mathrm{mg} \mathrm{L}^{-1}\right),(\mathrm{a} 1, \mathrm{~b} 1)\right)$ found near Station 3 or close to the Vouga River corresponds to a local anomaly situation, reflecting a severe DO depletion condition, where its consumption or loss due to exchanges with the atmosphere exceeds production. Nevertheless, this condition does not represent the entire lagoon but rather a localized shallow area during neap tide and after a low tide situation. 
Table 7. $\Delta(\mathrm{PC})$ metrics for BS/SC1 and BS/SC2, and for the lagoon stations (St1-St8).

\begin{tabular}{|c|c|c|c|c|c|}
\hline Stations & Scenarios & $\begin{array}{c}\text { Minimum } \\
\mathrm{mg} \mathrm{L}^{-1}\end{array}$ & $\begin{array}{c}\text { Maximum } \\
\mathrm{mg} \mathrm{L}^{-1}\end{array}$ & $\begin{array}{l}\text { Average } \\
\mathrm{mg} \mathrm{L}^{-1}\end{array}$ & $\begin{array}{c}\text { Standard } \\
\text { Deviation } \\
\mathrm{mg} \mathrm{L}^{-1}\end{array}$ \\
\hline \multirow[t]{2}{*}{ St1 } & BS-SC1 & -0.1 & 0.1 & 0.0 & 0.0 \\
\hline & BS-SC2 & -0.5 & 0.0 & -0.2 & 0.1 \\
\hline \multirow[t]{2}{*}{ St2 } & BS-SC1 & -0.1 & 0.3 & -0.1 & 0.0 \\
\hline & BS-SC2 & -0.9 & -0.3 & -0.6 & 0.1 \\
\hline \multirow[t]{2}{*}{ St3 } & BS-SC1 & -0.2 & 0.4 & -0.1 & 0.1 \\
\hline & BS-SC2 & -0.9 & 0.1 & 0.5 & 0.2 \\
\hline \multirow[t]{2}{*}{ St 4} & BS-SC1 & -0.1 & 0.6 & 0.0 & 0.1 \\
\hline & BS-SC2 & -0.8 & 0.3 & -0.5 & 0.3 \\
\hline \multirow[t]{2}{*}{ St5 } & BS-SC1 & -0.1 & 0.1 & 0.0 & 0.0 \\
\hline & BS-SC2 & -0.9 & -0.2 & -0.7 & 0.2 \\
\hline \multirow[t]{2}{*}{ St6 } & BS-SC1 & -0.2 & 0.2 & -0.1 & 0.0 \\
\hline & BS-SC2 & -0.6 & 0.0 & -0.4 & 0.1 \\
\hline \multirow[t]{2}{*}{ St7 } & BS-SC1 & -0.1 & 0.4 & 0.0 & 0.1 \\
\hline & BS-SC2 & -1.2 & -0.2 & -0.9 & 0.3 \\
\hline \multirow[t]{2}{*}{ St8 } & BS-SC1 & -0.2 & 0.2 & -0.1 & 0.0 \\
\hline & BS-SC2 & -1.2 & -0.7 & -1.0 & 0.1 \\
\hline
\end{tabular}

Table 8. $\Delta(\mathrm{DO})$ metrics for BS/SC1 and BS/SC2, and the lagoon stations (St1-St8).

\begin{tabular}{|c|c|c|c|c|c|}
\hline Stations & Scenarios & $\begin{array}{c}\text { Minimum } \\
\mathrm{mg} \mathrm{L}^{-1}\end{array}$ & $\begin{array}{c}\text { Maximum } \\
\mathrm{mg} \mathrm{L}^{-1}\end{array}$ & $\begin{array}{l}\text { Average } \\
\mathrm{mg} \mathrm{L}^{-1}\end{array}$ & $\begin{array}{c}\text { Standard } \\
\text { Deviation } \\
\mathrm{mg} \mathrm{L}^{-1}\end{array}$ \\
\hline \multirow[t]{2}{*}{ St1 } & BS-SC1 & -0.5 & -0.1 & -0.3 & 0.0 \\
\hline & BS-SC2 & -1.2 & 0.0 & -0.4 & 0.1 \\
\hline \multirow[t]{2}{*}{ St2 } & BS-SC1 & 0.0 & 0.0 & 0.0 & 0.0 \\
\hline & BS-SC2 & -0.8 & 4.2 & 0.6 & 0.3 \\
\hline \multirow[t]{2}{*}{ St3 } & BS-SC1 & -0.1 & 3.1 & 1.5 & 0.2 \\
\hline & BS-SC2 & 0.1 & 6.3 & 3.2 & 0.2 \\
\hline \multirow[t]{2}{*}{ St4 } & BS-SC1 & -3.1 & 3.2 & 0.1 & 0.1 \\
\hline & BS-SC2 & -4.2 & 2.1 & -0.5 & 0.1 \\
\hline \multirow[t]{2}{*}{ St5 } & BS-SC1 & -0.1 & 0.1 & 0.0 & 0.0 \\
\hline & BS-SC2 & -2.0 & 2.6 & -0.8 & 0.2 \\
\hline \multirow[t]{2}{*}{ St6 } & BS-SC1 & 2.1 & 0.1 & 1.0 & 0.1 \\
\hline & BS-SC2 & -3.9 & -0.2 & -0.1 & 0.1 \\
\hline \multirow[t]{2}{*}{ St7 } & BS-SC1 & -0.1 & 0.0 & 0.1 & 0.1 \\
\hline & BS-SC2 & -2.1 & 0.4 & -0.1 & 0.1 \\
\hline \multirow[t]{2}{*}{ St8 } & BS-SC1 & 0.0 & 0.1 & 0.1 & 0.0 \\
\hline & BS-SC2 & -2.2 & -1.7 & -1.7 & 0.1 \\
\hline
\end{tabular}



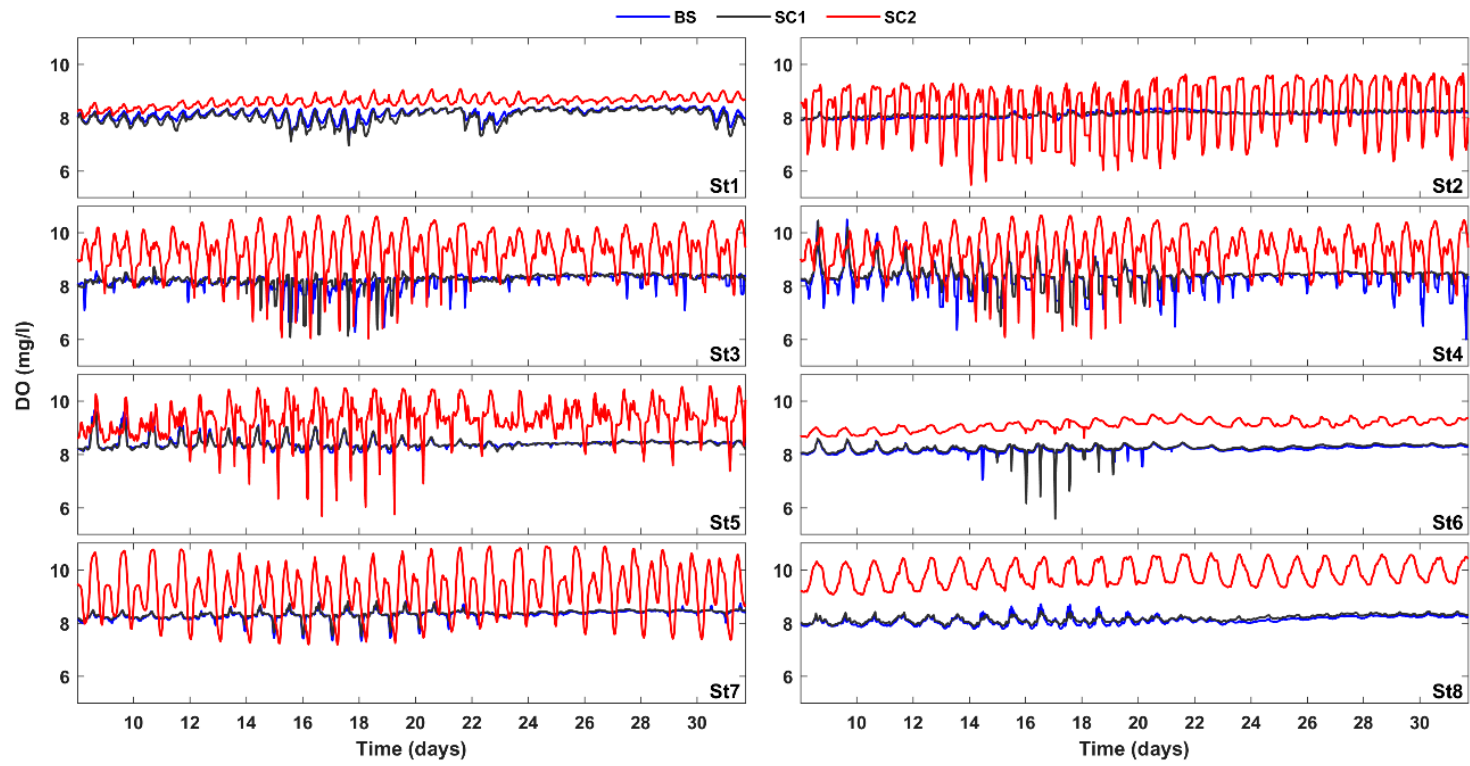

Figure 15. DO time series for the baseline (BS) and the scenarios SC1 and SC2 for all the lagoon stations under analysis (St1-St8).
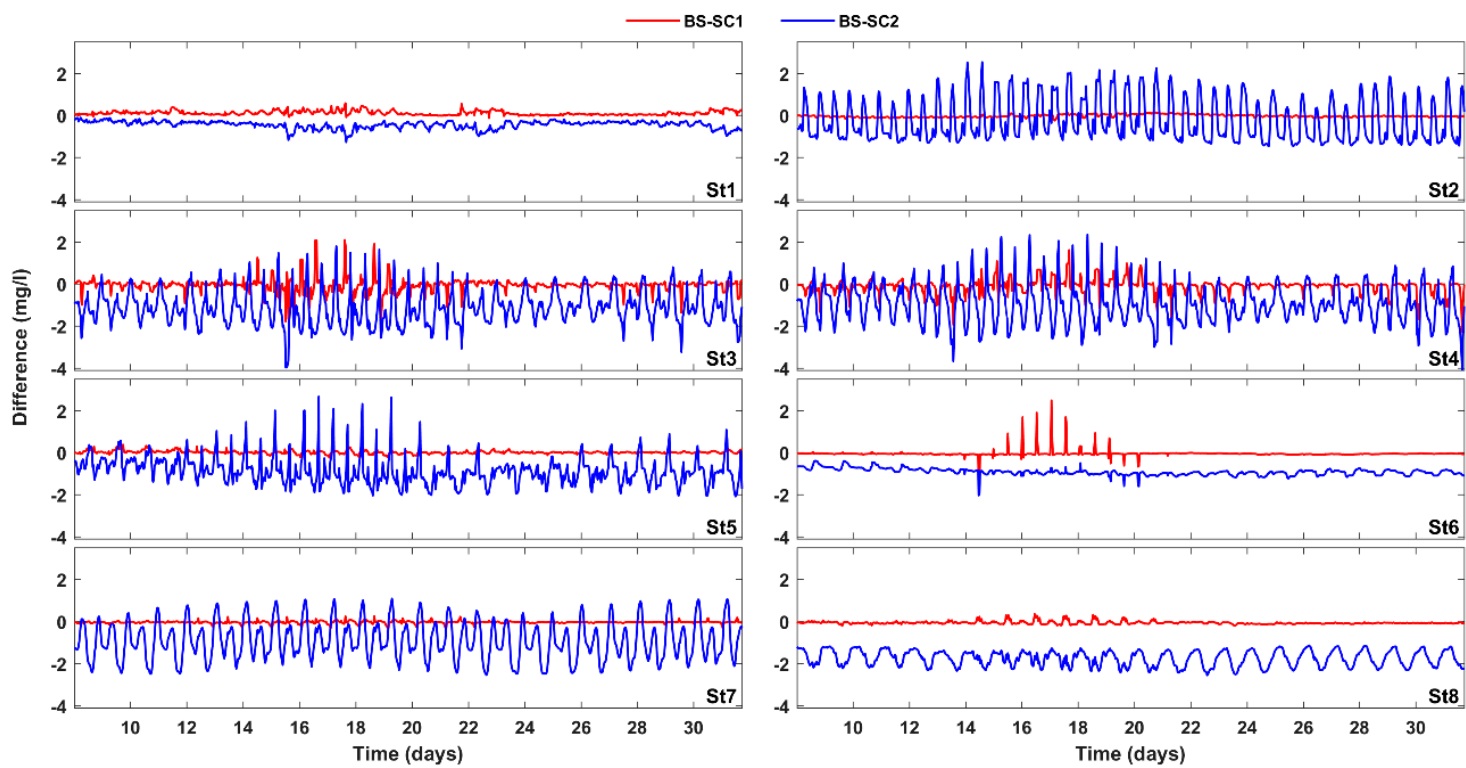

Figure 16. $\Delta(\mathrm{DO})$ time series for the differences between the baseline (BS) and each scenario SC1 and SC2 for all the lagoon stations under analysis (St1-St8). 

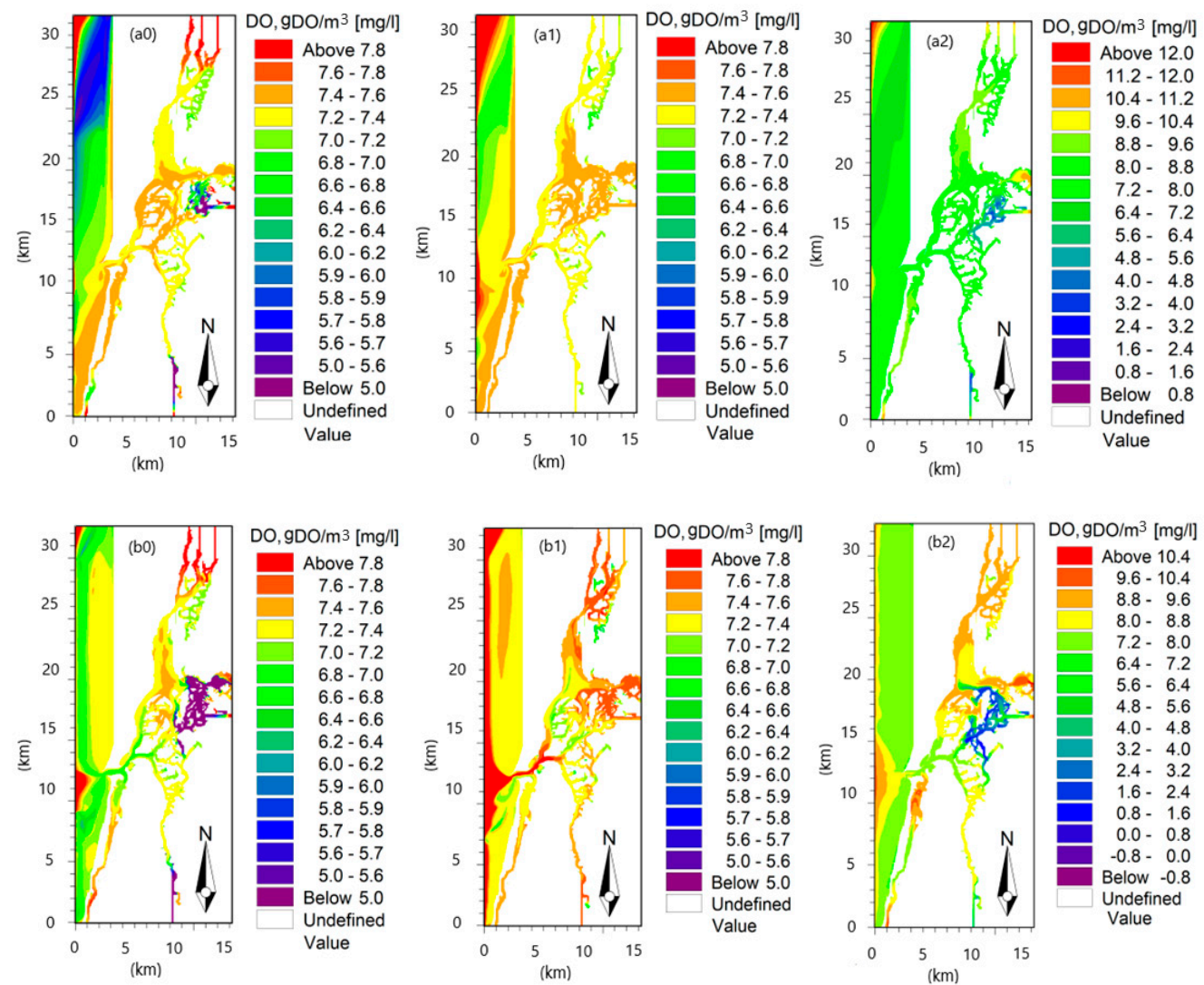

Figure 17. DO (mg L $\left.{ }^{-1}\right)$ snapshots for BS (a0,b0), SC1 (a1,b1), and SC2 (a2,b2) for two instants: (a)-neap/high tide at the lagoon mouth (day 25); (b)-spring/low tide at the lagoon mouth (day 16).

\subsection{The Wet Summer Situation (SC2)}

This section presents the SC2 scenario results corresponding to the wet summer situation as presented in Table 3.

Figure 3 (red lines) and Figure 4 (blue lines) present a consistent salinity drop for SC2 compared to BS, as D(salinity) shows values as low as 30 PSU, decreasing to 15 PSU due to the influence of the ocean water. It is worth noting that St2, despite the proximity to the ocean boundary, shows abnormal salinity values, as low as 5 PSU, compared to typical values ( $\sim 30$ PSU). This results from the transport of freshwater from the Vouga River during the ebb flow of spring tide. Indeed, the snapshots of the horizontal distribution of the salinity for SC2 (Figure 5) evidence a situation for which the salinity is low for most of the lagoon (blue color, $<10 \mathrm{PSU}$ ), revealing that the ocean dominance is restricted to the area near the lagoon mouth, where the mix-water front ( 17 PSU) is located. Likewise, SC2 presents a consistent water temperature increase compared to BS (Figure 6 (red lines)), as $\mathrm{D}$ (temperature) time series (Figure 7, blue lines; Table 5) show absolute values ranging within $0.5-2{ }^{\circ} \mathrm{C}$. Indeed, SC2 presents high water temperature values in the range of $20-22{ }^{\circ} \mathrm{C}$, where the maximum values are observed in the river areas and heads of the channels (St4, St5, and St6) during spring tide. Figure 8(a2) presents snapshots of the water temperature horizontal distribution for neap/high tide for SC2. It can be observed that the inland areas show an almost uniform distribution of high water temperature $\left(\sim 22^{\circ} \mathrm{C}\right)$, resulting from the combination of two physical factors: (a) during the neap tide, the water column is shallower and therefore heats up more easily, and (b) the ebb flow transports warm water to the central lagoon areas. During the spring/low tide (b2), both the ocean cold water $\left(\sim 18-19^{\circ} \mathrm{C}\right)$ and the warm waters from the river areas and heads of the channels $\left(\sim 23-24{ }^{\circ} \mathrm{C}\right)$ are transported by the strong tidal currents, generating higher dilution rates and a mix-water situation inside the lagoon. 
The time series (Figure 9, red lines) for SC2 shows a wide range of variations $\left(2-6 \mathrm{mg} \mathrm{L}^{-1}\right)$, with significantly high values compared to BS, where the maximum values are observed at the stations located at river areas and heads of the channels. It is worth noting the extremely high values observed at St1 and St2 $\left(2-4 \mathrm{mg} \mathrm{L}^{-1}\right)$, as well as at St5 $\left(6 \mathrm{mg} \mathrm{L}^{-1}\right)$. Indeed, the $\Delta(\mathrm{IN})$ time series (Figure 10, blue lines; Table 6) present absolute values in a high range of values $\left(1-5 \mathrm{mg} \mathrm{L}^{-1}\right)$, representing a significant concentration increase. The IN horizontal distribution snapshots for SC2 (Figure 11(a2,b2)) evidence a north-south gradient, with the northern areas of the lagoon presenting very high concentration values $\left(\sim 6 \mathrm{mg} \mathrm{L}^{-1}\right)$, while the central and the southern areas show lower typical maximum values $\left(\sim 2 \mathrm{mg} \mathrm{L}^{-1}\right)$. Indeed, as the ocean water flows toward the central area during the flooding, it transports low concentration water $\left(<0.6 \mathrm{mg} \mathrm{L}^{-1}\right)$ that dilutes the water in the southern and the central lagoon areas. Therefore, the IN distribution, even in a wet scenario, is dominated by the ocean flow.

Figure 12 (red lines) and Figure 13 (blue lines) present the PC and $\Delta$ (PC) time series for SC2. The time evolution shows mainly semi-diurnal variations, while a small-amplitude fortnight oscillation associated with the spring-neap modulation $\left(\sim 0.4 \mathrm{mg} \mathrm{L}^{-1}\right)$ is observed, as depicted in Figure 13. High concentration values $\left(\sim 1.2 \mathrm{mg} \mathrm{L}^{-1}\right)$ were reached in most of the stations, evidencing an overall concentration increase comparing to BS, as summarized in Table 8, which depicts negative $\Delta(\mathrm{PC})$ with absolute values within $\left(0.4-1.4 \mathrm{mg} \mathrm{L}^{-1}\right)$. Furthermore, PC horizontal distribution snapshots (Figure 14(a2,b2) highlight the establishment of a bloom located in the northern area of the lagoon, as well as along the Mira Channel (PC 1.5 mg L${ }^{-1}$ ), while the southern and the central areas still show moderate concentration values $\left(\sim 0.5 \mathrm{mg} \mathrm{L}^{-1}\right)$, although in the higher range found for BS.

Figure 15 (red lines) and Figure 16 (blue lines) present the DO and $\Delta(\mathrm{DO})$ time series for SC2. It can be observed that, similarly to phytoplankton, the time evolution does not present any significant semi-diurnal and fortnight modulation. High DO concentrations, within the range of 8-11 $\mathrm{mg} \mathrm{L}^{-1}$, as well as high-amplitude diurnal oscillations $\left(\sim 2 \mathrm{mg} \mathrm{L}^{-1}\right)$, are observed, corresponding to a significant increase in concentration comparing to BS, as summarized in Table 8. Indeed, DO horizontal distribution snapshots (Figure 17(a2,b2)) depict a generalized concentration increase, corresponding to high ranges of DO concentration values, except for the localized (near St3) hypoxia situation $\left(<6 \mathrm{mg} \mathrm{L}^{-1}\right)$ observed for BS and SC1.

\subsection{The Taylor Diagram for the Scenarios}

This section presents the Taylor diagrams (Figures 18-21a,b) for the two scenarios SC1 and SC2 and for all lagoon stations (represented by points M1 to M8, corresponding to the stations St1 to St8). Each diagram presents the RMSD, the standard deviation values, and the correlation coefficients, as defined in (1). For convenience, only the following variables are presented: salinity, water temperature, IN, and PC. The diagrams plot both RMSD versus the standard deviation, as defined in Section 3, and allow a qualitative comparison of the gap between the scenarios and the baseline, measured by RMSD. 

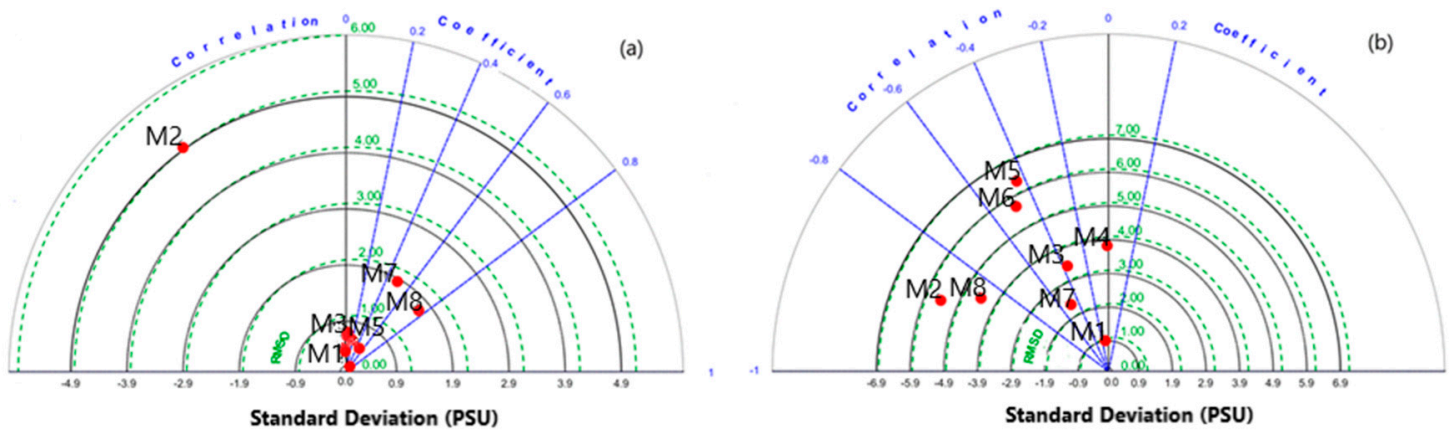

Figure 18. Salinity RMSD contours (PSU, in green, dashed) in the Taylor diagrams for the scenarios SC1 (a) and SC2 (b) and the lagoon stations (M1 (as St1) to M8 (as St8)).
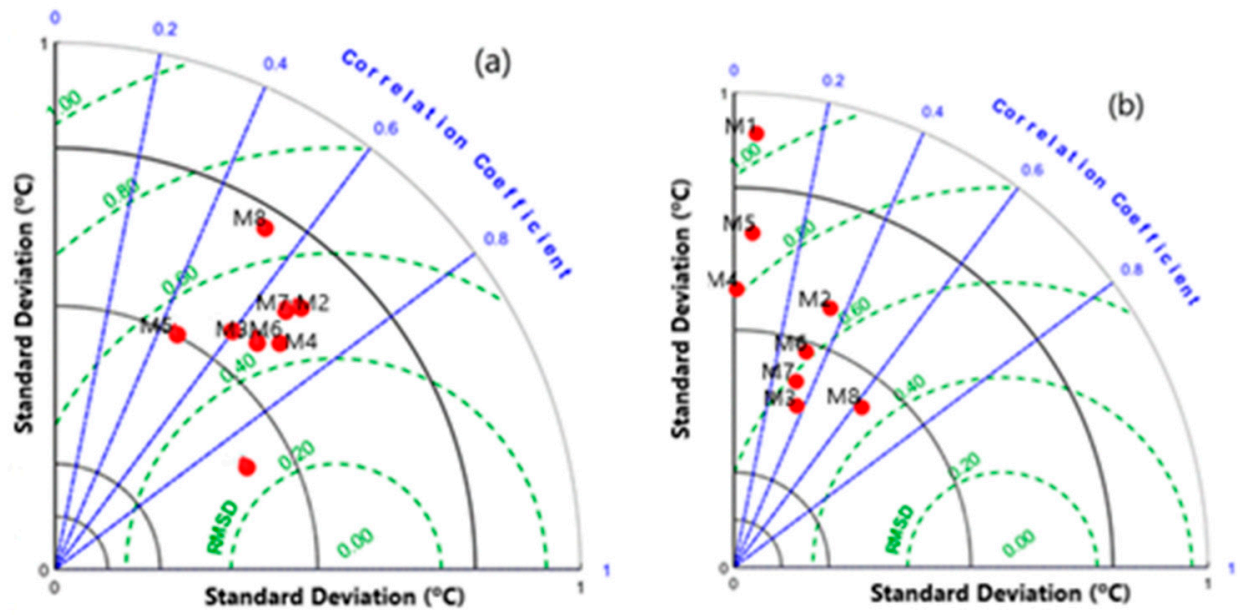

Figure 19. Water temperature RMSD contours ( ${ }^{\circ} \mathrm{C}$, in green, dashed) in the Taylor diagrams for the scenarios SC1 (a) and SC2 (b) and the lagoon stations (M1 (as St1) to M8 (as St8)).
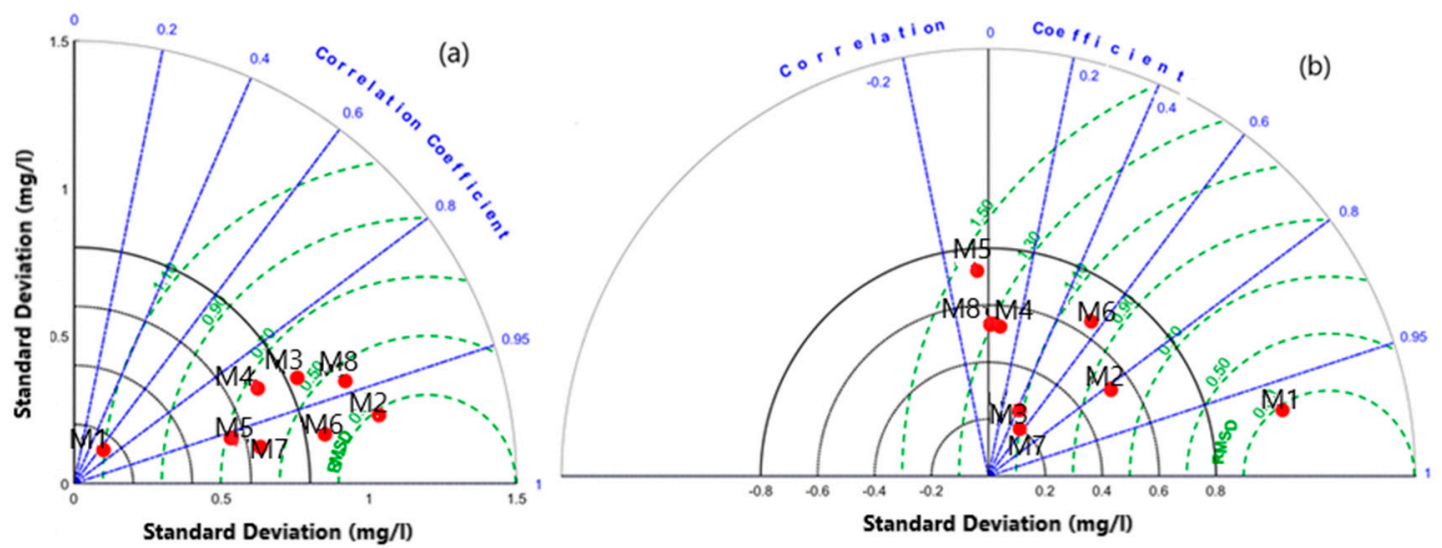

Figure 20. IN RMSD contours (mg L ${ }^{-1}$, in green, dashed) in the Taylor diagrams for the scenarios SC1 (a) and SC2 (b) and for the lagoon stations (M1 (as St1) to M8 (as St8)). 

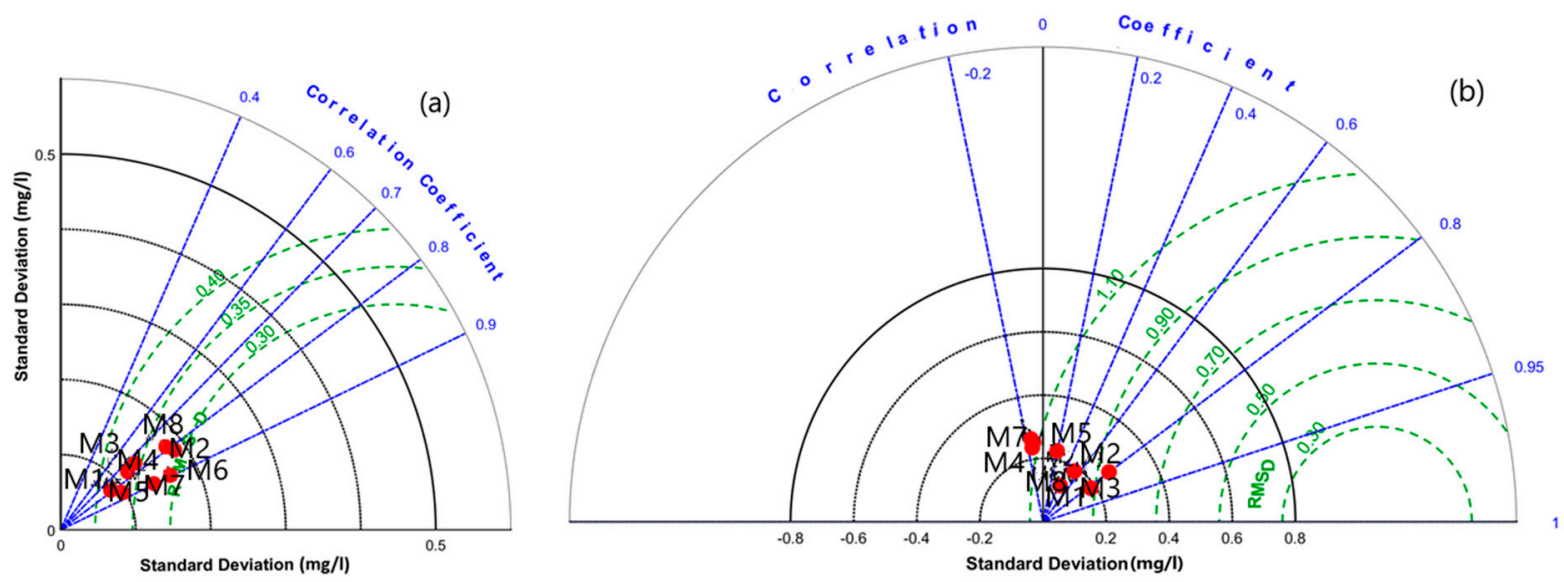

Figure 21. PC RMSD (contours $\mathrm{mg} \mathrm{L}^{-1}$, in green, dashed) in the Taylor diagrams for the scenarios SC1 (a) and SC2 (b) and stations (M1 (as St1) to M8 (as St8)).

The salinity, water temperature, IN, and PC RMSD values for SC1 are quite moderate and typical (respectively, $<1{ }^{\circ} \mathrm{C},<2 \mathrm{PSU}, 0.3-0.7 \mathrm{mg} \mathrm{L}^{-1}$, and $0.3-04 \mathrm{mg} \mathrm{L}^{-1}$ ), excluding some discrepancies observed for salinity at M2 ( 5PSU) and IN at M1 $\left(1.1 \mathrm{mg} \mathrm{L}^{-1}\right)$. Concerning SC2, the water temperature shows similar RMSD values as for SC1, with the last case presenting slightly higher values (between 0.4 and $1.0^{\circ} \mathrm{C}$ ), while $\mathrm{SC} 2$ presents higher values for salinity (up to 7 PSU), IN $\left(0.4-1.5 \mathrm{mg} \mathrm{L}^{-1}\right)$, and PC (0.7-1.1 $\mathrm{mg} \mathrm{L}^{-1}$ ). Furthermore, except for PC, where a cluster pattern is observed, reflecting a tight interval of RMSD values and correlation coefficients, the points are more scattered distributed for $\mathrm{SC} 2$, reflecting the disturbance between the scenario and the baseline.

\section{Discussion}

Although EWEs are very short-lasting phenomena, the increase in their frequency or intensity may durably change the physical conditions of natural coastal ecosystems, inducing physical and biogeochemistry stresses and ultimately challenging the resilience of resident species. Therefore, the present study aims to assess the physical and biogeochemistry status and patterns of the Ria de Aveiro Lagoon under extreme-event scenarios induced by the combined effects of tide and river discharges. The baseline simulation, BS, describes a typical summer situation of the lagoon, as a shallow tidal-dominated and well-mixed system, under the combined influence of the ocean and river freshwater, as described by several authors in previous studies $[41,50,51,56,57]$. The present results show that the lagoon under the baseline conditions is characterized by low salinity and water temperature oscillations ( 2 PSU and $1{ }^{\circ} \mathrm{C}$ ) and by their high values $(30-34$ PSU and $18.0-20^{\circ} \mathrm{C}$, respectively), which are regulated by semi-diurnal and fortnight modulation. The small-amplitude oscillations of both salinity and water temperature depict a horizontal and vertical well-mixed waterbody for a lagoon almost filled with seawater, as evidenced by the horizontal distributions. The major disturbance, corresponding to the highest range of oscillations (30-15 PSU and 18.0-24 ${ }^{\circ} \mathrm{C}$, respectively), are observed near the river areas and heads of the channels, during ebb flow and spring tide period, when the river flow influence is enhanced. Indeed, due to the input of a reduced volume of freshwater compared to the ocean tidal prism [43-45], the mixed-water boundaries remain located near the river areas and the heads of the channels. These are increasingly pushed farther toward the river's mouth during the spring tide and flood, leading to high salinity values at the upper lagoon heads, while the ebb flow still transports brackish water downstream toward the central lagoon areas. The biogeochemistry variables reflect the dynamics of the lagoon, namely the salinity patterns. Indeed, under BS, the inorganic nitrogen, IN, shows a typical estuarine horizontal gradient distribution, with lower concentration values found near the ocean boundary $\left(<<1 \mathrm{mg} \mathrm{L}^{-1}\right)$, while river areas and heads of the channels present the higher but moderate values $\left(\sim 1 \mathrm{mg} \mathrm{L}^{-1}\right)$. Likewise, the phytoplankton carbon (PC) presents 
small concentration variations $\left(<0.1 \mathrm{mg} \mathrm{L}^{-1}\right)$, while moderate values $\left(\sim 0.1-0.2 \mathrm{mg} \mathrm{L}^{-1}\right)$ are observed for dry conditions, except for the river areas and heads of the channels, where high-amplitude oscillation and values are observed (up to $0.5 \mathrm{mg} \mathrm{L}^{-1}$ ) during spring tide. This result suggests that even during dry situations, no limiting phytoplankton growth was found. Indeed, nutrients accumulated from the river output near the river areas and heads of the channels may be mobilized into the flow and dispersed toward the main areas and made available for the residual phytoplankton growth. DO shows moderate concentration values $\left(\sim 8 \mathrm{mg} \mathrm{L}^{-1}\right)$ and no significant amplitude fluctuations, except near localized sallow areas where were found low values $\left(\sim 6 \mathrm{mg} \mathrm{L}^{-1}\right)$ during low water of neap tide. This result may reflect, besides the oxygen consumption, low oxygen production by the phytoplankton or the increased oxygen loss to the atmosphere due to the higher water temperature.

\section{The Scenarios}

Under the dry scenario, SC1, corresponding to the river's discharge reduction, no significant salinity changes comparing to the summer baseline were found, as shown in the salinity time evolution and horizontal patterns. In contrast to BS, where important salinity oscillations (30-15 PSU) were identified during the spring tide period at the river areas and heads of the channels, the salinity values are almost constant everywhere and close to those of the seawater ( 34 PSU). This shows a lagoon mostly infilled with ocean salty water, reflecting the influence of oceanic waters up to the river areas and heads of the channels. The water temperature reflects the heat budget within the water column, namely the competing influence between the solar radiation and the surface heat exchange, as well as the exchange between cold ocean and warm lagoon water in the inner areas. Indeed, a decrease in the water temperature up to $1.5^{\circ} \mathrm{C}$ during the spring tide evidences the signature of the ocean cold water, as in the salinity distribution. IN showed a concentration reduction, reflecting the dominant influence of the ocean water. Indeed, the decrease in the river flow contributes to lower IN concentration values, not only due to the input reduction at the river boundaries but also due to the contribution of the ocean's low concentrated water. PC and DO showed moderate reduction $\left(\sim 0.2\right.$ and $1.0 \mathrm{mg} \mathrm{L}^{-1}$, respectively) comparing to the baseline values, reflecting some phytoplankton growth despite the low IN concentration environment.

Under the wet summer scenario, SC2, resulting from the significant increase in river discharge comparing to the baseline, consistent salinity changes in a time period of some tidal cycles are observed: the freshwater influence goes beyond the central lagoon areas, reaching its mouth, namely during spring tide. The salinity values at the central areas drop from the typical $\sim 30 \mathrm{PSU}$, as observed for BS, to mix-water values ( 15-20 PSU), while the river areas and heads of the channels present typical freshwater characteristics ( $<5 \mathrm{PSU})$. The water temperature values vary within the range of $20-22^{\circ} \mathrm{C}$, corresponding to an overall increase in the water temperature $\left(\Delta\right.$ (temperature) $\sim 0.5-2{ }^{\circ} \mathrm{C}$ ) for this scenario. This reflects again the mix-waters situation of the lagoon, driven by the ebb flow from the river areas and heads of the channels, as well as the inertia of the water column to the water temperature changes. The biochemistry variables concentration increases considerably, with $\Delta|\mathrm{IN}|,|\Delta(\mathrm{PC})|, \alpha v \delta|\Delta(\mathrm{DO})|$ showing high values, ranging within, respectively, 1-5 mg L $\mathrm{m}^{-1}, 2-6 \mathrm{mg} \mathrm{L}^{-1}$, and 2-4 $\mathrm{mg} \mathrm{L}^{-1}$, which reflects the tidal dynamics influence on the physical and the biogeochemistry of the lagoon. Finally, Taylor diagrams were used as a valuable tool to assess the scenario results, although underestimating the maximum range of RMSD variations for the scenarios. Indeed, the results showed that while water temperature shows moderate RMSD values for both scenarios, salinity, IN, and PC presented, respectively, moderate RMSD values for SC1, while significant for SC2, reflecting, respectively, small and high departure to BS. It is worth pointing out that these results are globally consistent and coherent with what was previously found. On the other hand, EWEs are being more and more associated with climate change [58], their frequencies and intensities recurrently and continuously increasing throughout various coastal ecosystems 
around the globe. A fundamental question remains whether the fingerprints of these events disappear or remain after each extreme condition. Indeed, several studies highlighted that EWEs are affecting not only the phytoplankton abundances and composition but also the food webs and the biogeochemical cycles of coastal ecosystems. For instance, Charria et al. [59] evidenced the signature of EWEs in the Bay of Brest and highlighted the link between local rivers and changes in salinity, revealing that coastal waters of Western Europe are not only significantly connected to large-scale atmospheric conditions and patterns, but also local-scale drivers such as river discharges. Pearl et al. [60] emphasized the impact of EWEs on the Neuse River Estuary, USA ecosystem and showed that about half of the variation in picophytoplankton abundance was explained by the environmental variables, the temperature explaining the most variation, followed by the change in total dissolved nitrogen concentration, reflecting the river discharge influence. Kurtay et al. [61] highlighted the influence of EWEs in changes in plankton composition in continental shelf waters.

\section{Concluding Remarks}

The study presented two scenarios representing extreme meteorological events in the Ria de Aveiro Lagoon coastal area, taking into account the sea-level rise predicted for the Portuguese coastal area. In general, the departure from the baseline functioning of the lagoon physical patterns (namely salinity and water temperature) demonstrates its response essentially to the main physical drivers. This is not surprising, as salinity, and to a lesser extent, the water temperature, represents, in general, a good sign of the main hydrodynamic feature of coastal lagoons. Under a dry summer scenario represented by a reduction in the river flow, the lagoon is likely to shift from a mix-water situation to one dominated by the cold ocean water $\left(30-34 \mathrm{PSU} ; 18^{\circ} \mathrm{C}\right)$, potentially generating a salinity intrusion until the upper reaches, as seawater is transported up to the heads of the channels. Likewise, the inflow of waters with low nutrients concentration results in a net decrease in concentration of the nutrients along the lagoon channels, leading, therefore, to a long-term reduction in the phytoplankton population. Nevertheless, spring tide ebb flows transport nutrients from the river mouths to the central lagoon areas, supporting the phytoplankton growth. On the other hand, favorable conditions for the hypoxia state ( $\mathrm{DO}<6 \mathrm{mg} \mathrm{L}^{-1}$ ) may be generated under dry conditions at some localized shallow areas, during low or neap tides, due to oxygen losses to the atmosphere and related biogeochemistry processes within the water column. Under a wet summer scenario, the lagoon easily shifted to a generalized brackish and warmer situation ( $\left.<15 \mathrm{PSU} ; \sim 21^{\circ} \mathrm{C}\right)$. This result comes from the combined effect of the tidal transport and river discharge, which is enhanced during the ebb flow of spring tides that generate the transport of fresh and warmer water from the channels heads to the lagoon central areas and mouth. Likewise, nutrient and phytoplankton dynamics depict short-term and local-scale variability.

The main conclusions of this work can be summarized in the following points. Firstly, results from previous studies [43-45] are confirmed, evidenced that tides are the dominant driving force of the system, imposing its fingerprint on all identified patterns, which feature a mostly semi-diurnal and fortnight time scale. Changes in water temperature and intrusion of saltwater at the channel heads and transport of brackish water to areas close to the ocean seem to be the most important results. Secondly, although EWEs (under a sea-level rise scenario) affect primarily the physical conditions of the water column (namely salinity and water temperature) by generating transient and local salinity changes, no eutrophication or oligotrophic situations are expected to be generated, as no light- and nutrient-limiting condition is likely to occur. Assessing the impact of EWEs on ecosystem biogeochemistry remains an open subject and a challenge, as their importance is now increasingly recognized for their impacts on the short- and long-term variabilities. It can be concluded that further investigations are, therefore, still needed to better understanding how EWEs influence the biogeochemistry of coastal ecosystems and the shift in the species distribution and the population dynamics, including composition, diversity, and community structure. 
Author Contributions: J.F.L. proposed the topic, conceived and designed the study, including the numerical simulations, the result analysis, discussion, and revision. He constructed and edited the manuscript. C.L.L. conducted the data post-processing and contributed to the characterization of the study area, as well as to the result analysis, discussion, and manuscript revision. J.M.D. supervised C.L.L. works and contributed to the final revision of the manuscript. All authors have read and agreed to the published version of the manuscript.

Funding: This work is a contribution to project ASHMOB (PTDC/ASP-SIL/29351/2017) funded by FCT-Fundação para a Ciência e a Tecnologia, I.P., through national funds, and the co-funding by the FEDER, within the PT2020 Partnership Agreement and Compete 2020. Thanks are due to FCT/MCTES for the financial support to CESAM (UIDP/50017/2020+UIDB/50017/2020) through national funds. C.L.L. is funded by national funds through the FCT-Foundation for Science and Technology, I.P., under the project CEECIND/00459/2018.

Institutional Review Board Statement: Not applicable.

Informed Consent Statement: Informed consent was obtained from all subjects involved in the study.

Data Availability Statement: The data used in this study was obtained from the project framework (ModelRia [47]) in which the authors are fully co-responsible for its use.

Acknowledgments: The authors thank the reviewers for their patience and effort in reviewing the article, as well as the publisher for the final formatting.

Conflicts of Interest: The authors declare no conflict of interest.

\section{Nomenclature}

$\begin{array}{ll}\text { SLR: MSLR } & \text { Sea-level rise, mean sea-level rise } \\ \text { EWEs } & \text { Extreme weather events } \\ \text { IN } & \text { Inorganic nitrogen } \\ \text { PC } & \text { Phytoplankton carbon } \\ \text { BS } & \text { Baseline simulation }\end{array}$

\section{References}

1. Ummenhofer, C.C.; Meehl, G.A. Extreme weather and climate events with ecological relevance: A review. Philos. Trans. R. 2017, 372, 20160135. [CrossRef]

2. Herring, S.C.; Hoerling, M.P.; Kossin, J.P.; Peterson, T.C.; Stott, P.A. Explaining extreme events of 2014 from a climate perspective. Bull. Am. Meteorol. Soc. 2015, 96, S1-S172. [CrossRef]

3. Alexander, L.V.; Zhang, X.; Peterson, T.C.; Caesar, J.; Gleason, B.; Klein-Tank, A.M.G.; Haylock, M.; Collins, D.; Trewin, B.; Rahimzadeh, F.; et al. Global observed changes in daily climate extreme of temperature and precipitation. J. Geoph. Res. 2006, 111, DO5109. [CrossRef]

4. Goswami, B.N.; Venugopal, V.; Sengupta, D.; Madhusoodanan, S.; Xavier, P.X. Increasing trend of extreme rain events over India in a warming environment. Science 2006, 314, 1442-1445. [CrossRef]

5. Griffiths, M.L.; Bradley, R.S. Variation of twentieth-century temperature and precipitation extreme indicators in the Northeast United States. J. Clim. 2007, 20, 5401-5417. [CrossRef]

6. Smith, T.M.; Reynolds, R.W.; Peterson, T.C.; Lawrimore, J. Improvements to NOAA's historical merged land-ocean surface temperature analysis (1880-2006). J. Clim. 2008, 21, 2283-2296. [CrossRef]

7. Keenlyside, N.S.; Latif, M.; Jungclaus, J.; Kornblueh, L.; Roeckner, E. Advancing decadal-scale climate prediction in the North Atlantic Sector. Nature 2008, 453, 84-88. [CrossRef]

8. IPCC. Managing the risks of extreme events and disasters to advance climate change adaptation. In A Special Report of Working Groups I and II of the Intergovernmental Panel on Climate Change; Field, C.B., Barros, V., Stockerp, T.F., Dahe, Q., Dokken, D.J., Ebi, K.R.L., Mastrandrea, M.D., Mach, K.J., Plattner, G.-K., Allen, S.K., et al., Eds.; Cambridge University Press: Cambridge, UK; New York, NY, USA, 2012; p. 582.

9. Stott, P. How climate change affects extreme weather events. Science 2016, 352, 1517-1518. [CrossRef]

10. Church, J.A.; Clark, P.U.; Cazenave, A.; Gregory, J.M.; Jevrejeva, S.; Levermann, A.; Merrifield, M.A.; Milne, G.A.; Nerem, R.S.; Nunn, P.D.; et al. Sea level change. In Climate Change 2013: The Physical Science Basis. Contribution of Working Group I to the Fifth Assessment Report of the Intergovernmental Panel on Climate Change; Stocker, T.F., Qin, D., Plattner, G.-K., Tignor, M., Allen, S.K., Boschung, J., Nauels, A., Xia, Y., Bex, V., Midgley, P.M., Eds.; Cambridge University Press: Cambridge, UK; New York, NY, USA, 2013; pp. 1137-1216. 
11. IPCC. Summary for Policymakers. In Climate Change 2014: Impacts, Adaptation, and Vulnerability. Part A: Global and Sectoral Aspects. Contribution of Working Group II to the Fifth Assessment Report of the Intergovernmental Panel on Climate Change Cambridge; Field, C.B., Barros, V.R., Dokken, D.J., Mach, K.J., Mastrandrea, M.D., Bilir, T.E., Chatterjee, M., Ebi, K.L., Estrada, Y.O., Genova, R.C., et al., Eds.; Cambridge University Press: Cambridge, UK; New York, NY, USA, 2014.

12. Rahmstorf, S. A semi-empirical approach to projecting future sea-level rise. Science 2007, 315, 368-370. [CrossRef]

13. Le Bars, D. Uncertainty in sea level rise projections due to the dependence between contributors. Earths Future 2018, 6, 1275-1291. [CrossRef]

14. Nauels, A.; Malte Meinshausen, M.; Mengel, M.; Lorbacher, K.; Wigley, T.M.L. Synthesizing long-term sea level rise projectionsThe MAGICC sea level model. Geoscientific model development discussions. Geosci. Model. Dev. 2017, 10, 2495-2524. [CrossRef]

15. Pickering, M.; Horsburgh, K.J.; Blundell, J.R.; Hirschi, J.J.M.; Nicholls, R.J.; Verlaan, M.; Wells, N.C. The impact of future sea-level rise on the global tides. Cont. Shelf Res. 2017, 142, 50-68. [CrossRef]

16. Idier, D.; Paris, F.; Le Cozannet, G.; Boulahya, F.; Dumas, F. Sea-level rise impacts on the tides of the European Shelf. Cont. Shelf Res. 2017, 137, 56-71. [CrossRef]

17. Antunes, C.; Taborda, R. Sea level at cascais tide gauge: Data, analysis and results. J. Coast. Res. 2009, 56, $218-222$.

18. Lopes, C.L.; Silva, P.A.; Dias, J.M.; Rocha, A.; Picado, A.; Plecha, S.; Fortunato, A.B. Local sea level change scenarios for the end of the 21St century and potential physical impacts in the lower Ria de Aveiro (Portugal). Cont. Shelf Res. 2011, 31, 1515-1526. [CrossRef]

19. Cid, A.; Menéndez, M.; Castanedo, S.; Abascal, A.J.; Méndez, F.J.; Medina, R. Long-term changes in the frequency, intensity and duration of extreme storm surge events in southern Europe. Clim. Dyn. 2015, 14. [CrossRef]

20. IPCC. Climate change: Impacts, adaptation and vulnerability. In Contribution of Working Group II to the Fourth Assessment Report of the Intergovernmental Panel on Climate Change; Parry, M.L., Canziani, O.F., Palutikof, J.P., van der Linden, P.J., Hanson, C.E., Eds.; Cambridge University Press: Cambridge, UK; New York, NY, USA, 2007; p. 976.

21. Kumbier, K.; Carvalho, R.C.; Woodroffe, C.D. Modelling Hydrodynamic Impacts of Sea-Level Rise on Wave-Dominated Australian Estuaries with Differing Geomorphology. J. Mar. Sci. Eng. 2018, 6, 66. [CrossRef]

22. Yunzhu, Y.; Karunarathna, H.; Reeve, D.E. Numerical modelling of hydrodynamic and morphodynamic response of a meso-tidal estuary inlet to the impacts of global climate variabilities. Mar. Geol. 2019, 407, 229-247.

23. Yuan, B.; Sun, J.; Lin, B.; Zhang, F. Long-term morphodynamics of a large estuary subject to decreasing sediment supply and sea level rise. Glob. Planet. Chang. 2020, 191, 103212. [CrossRef]

24. Grases, A.; Gracia, V.; García-León, M.; Lin-Ye, J.; Sierra, J.P. Coastal Flooding and Erosion under a Changing Climate: Implications at a Low-Lying Coast (Ebro Delta). Water 2020, 12, 346. [CrossRef]

25. Quesada, M.C.C.; García-Lafuente, J.; Garel, E.; Cabello, J.D.; Martins, F.; Moreno-Navas, J. Effects of tidal and river discharge forcings on tidal propagation along the Guadiana Estuary. J. Sea Res. 2019, 146, 1-13. [CrossRef]

26. Bird, E.C.F. Physical setting and geomorphology of coastal lagoons. In Coastal Lagoon Processes; Kjerfve, B., Ed.; Elsevier: Amsterdam, The Netherlands, 1994; Volume 2, pp. 9-40.

27. Vargas, C.I.C.; Vaz, N.; Dias, J.M. An evaluation of climate change effects in estuarine salinity patterns: Application to Ria de Aveiro shallow water system. Estuar. Coast. Shelf Sci. 2017, 189, 33-45. [CrossRef]

28. Smith, M.D. The ecological role of climate extremes: Current understanding and future. J. Ecol. 2011, 99, 656-663. [CrossRef]

29. Blintz, J.C.; Nixon, S.; Buckley, B.; Granger, S. Impacts of temperature and nutrients on coastal lagoon plant communities. Estuaries 2003, 26, 765-776. [CrossRef]

30. Conley, D.J.; CarStensen, G.; Aertebjerg, P.B.; ChriStensen, T.; Dalsgaard, J.L.S.; Josefson, A.B. Long-term changes and impacts of hypoxia in Danish coastal waters. Ecol. Appl. 2007, 17, S165-S184. [CrossRef]

31. Oviatt, C.A. The changing ecology of temperate coastal waters during a warming trend. Estuaries 2004, 27, 895-904. [CrossRef]

32. Mackenzie, B.R.; Gislason, H.; Möllmann, C.; KöSter, F.W. Impact of 21St century climate change on the Baltic Sea fish community and fisheries. Global. Chang. Biol. 2007, 13, 1348-1367. [CrossRef]

33. Lloret, J.; Marín, A.; Marín-Guirao, L. Is coastal lagoon eutrophication likely to be aggravated by global climate change? Estuar Coast. Shelf Sci. 2008, 78, 403-412. [CrossRef]

34. Moore, M.V.; Pace, M.L.; Mather, J.R.; Murdoch, P.S.; Howarth, R.W.; Folt, C.L.; Driscoll, C.T. Potential effects of climate change on freshwater ecosystems of the New England/Mid Atlantic region. Hydrol. Process. 1997, 11, 925-947. [CrossRef]

35. Lopes, C.L.; Azevedo, A.; Dias, J.M. Flooding assessment under sea level rise scenarios: Ria de Aveiro case study. J. Coast. Res. 2013, 65, 766-771. [CrossRef]

36. Lopes, C.L.; Dias, J.M. Assessment of flood hazard during extreme sea levels in a tidally dominated lagoon. Nat. Hazards 2015, 77, 1345-1364. [CrossRef]

37. Lopes, C.L.; Alves, F.L.; Dias, J.M. Flood risk assessment in a coastal lagoon under present and future scenarios: Ria de Aveiro case Study. Nat. Hazards 2017, 89, 1307-1325. [CrossRef]

38. Lopes, C.L.; Dias, J.M. Tidal dynamics in a changing lagoon: Flooding or not flooding the marginal regions. Estuar. Coast. Shelf Sci. 2015, 167, 14-24. [CrossRef]

39. Génio, L.; Sousa, A.; Vaz, N.; Dias, J.M.; Barroso, C. Effect of low salinity on the survival of recently hatched veliger of Nassarius reticulatus (L.) in estuarine habitats: A case study of Ria de Aveiro. J. Sea Res. 2008, 59, 133-143. [CrossRef] 
40. Lopes, J.F.; Lopes, C.L.; Dias, J.M. Climate Change Impact in the Ria de Aveiro Lagoon Ecosystem: A Case Study. J. Mar. Sci. Eng. 2019, 7, 352. [CrossRef]

41. Dias, J.M. Contribution to the Study of the Ria de Aveiro Hydrodynamics. Ph.D. Thesis, Universidade de Aveiro, Aveiro, Portugal, 2001; p. 288.

42. Dias, J.M.; Lopes, J.F.; Dekeyser, I. Hydrological characterisation of Ria de Aveiro lagoon, Portugal, in early summer. Oceanol. Acta 1999, 22, 473-485. [CrossRef]

43. Dias, J.M.; Lopes, J.F.; Dekeyser, I. Lagrangian transport of particles in Ria de Aveiro lagoon, Portugal. Phys. Chem. Earth B 2001, 26, 729-734. [CrossRef]

44. Vicente, C.M. Caracterização Hidráulica e Aluvionar da Ria de Aveiro, Utilização de Modelos Hidráulicos no Estudo de Problemas da Ria. Jormadas Da Ria De Aveiro 1985, 3, 41-58.

45. Fortunato, A.B.; Rodrigues, M.; Dias, J.M.; Lopes, C.; Oliveira, A. Generating inundation maps for a coastal lagoon: A case study in the Ria de Aveiro (Portugal). Ocean Eng. 2013, 64, 60-71. [CrossRef]

46. Vaz, L.; Plecha, S.; Dias, J.M. Coastal wave regime influence on Ria de Aveiro inlet dynamics. J. Coast. Res. 2013, 65, 1605-1610. [CrossRef]

47. ModelRia. Modelação da Qualidade da Água na Laguna da Ria de Aveiro; Final Report; Instituto Superior Técnico-Centro de Ambiente e Tecnologias Marítimos and Hidromod, Universidade de Aveiro-Centro das Zonas CoSteiras e do Mar: Aveiro, Portugal, 2003.

48. Rodrigues, M.; Oliveira, A.; Queiroga, H.; Fortunato, A.; Zhang, Y. Three-dimensional modeling of the lower trophic levels in the Ria de Aveiro (Portugal). Ecol. Model. 2009, 220, 1274-1290. [CrossRef]

49. Almeida, M.A.; Cunha, M.A.; Alcântar, F. Relationship of bacterioplankton production with primary production and respiration in a shallow estuarine system, Ria de Aveiro, NW Portugal. Microbiol. Res. 2005, 160, 315-328. [CrossRef] [PubMed]

50. Lopes, C.B.; Lillebo, A.I.; Dias, J.M.; Pereira, E.; Vale, C.; Duarte, A.C. Nutrient dynamics and seasonal succession of phytoplankton assemblages in a Southern European Estuary: Ria de Aveiro, Portugal. Estuar. Coast. Shelf Sci. 2007, 71, 480-490. [CrossRef]

51. Lopes, J.F.; Almeida, M.A.; Cunha, M.A. Modelling the ecological patterns of a temperate lagoon in a very wet spring season. Ecol. Model. 2010, 221, 2302-2322. [CrossRef]

52. Redfield, A.C.; Ketchum, B.H.; Richards, F.A. The Influence of Organisms on the Composition of Seawater; Hill, M.N., Ed.; Interscience Publisher: New York, NY, USA, 1963; pp. 26-77.

53. Mike3. Hydrodynamic and Transport Module, A scientific Description, DHI Water and Environment. Denmark. 2017. Available online: http: / / www.dhisoftware.com (accessed on 15 April 2021).

54. Mike3. Eutrophication Model, A Scientific Description, ECO Lab-A Numerical Laboratory for Ecological Modelling, DHI Water and Environment. Denmark. 2017. Available online: http:/ / www.dhisoftware.com (accessed on 15 April 2021).

55. Taylor, K.E. Summarizing multiple aspects of model performance in a single diagram. J. Geophys. Res. 2001, 106, 7183-7192. [CrossRef]

56. Dias, J.M.; Lopes, J.F.; DeKeyser, I. A numerical system to study the transport properties in the Ria de Aveiro lagoon. Ocean Dyn. 2003, 53, 220-231. [CrossRef]

57. Dias, J.; Lopes, J. Implementation and assessment of hydrodynamic, salt and heat transport models: The case of Ria de Aveiro Lagoon (Portugal). Environ. Model. Softw. 2006, 21, 1-15. [CrossRef]

58. NAS. Attribution of Extreme Weather Events in the Context of Climate Change. National Academies of 937 Sciences, Engineering, and Medicine; National Academies Press: Washington, DC, USA, 2016. [CrossRef]

59. Charria, G.; Rimmelin-Maury, P.; Goberville, E.; l'Helguen, S.; Barrier, N.; David-Beausire, C.; Cariou, T.; Grossteffan, E.; Répécaud, M.; Quéméner, L. Temperature and Salinity Changes in Coastal Waters of Western Europe: Variability. In Trends and Extreme Events. Evolution of Marine Coastal Ecosystems under the Pressure of Global Changes; Ceccaldi, H.J., Hénocque, Y., Komatsu, T., Prouzet, P., Sautour, B., Yoshida, J., Eds.; Springer: Cham, Switzerland, 2020; pp. 207-226. [CrossRef]

60. Paerl, R.W.; Venezia, R.E.; Sanchez, J.J.; Paerl, H.W. Picophytoplankton dynamics in a large temperate estuary and impacts of extreme storm events. Sci. Rep. 2020, 10, 1-15. [CrossRef]

61. Kurtay, G.; Prevost, H.J.; Stauffer, B.A. Pico- and nanoplankton communities on a near to offshore transect along the continental shelf of the northwestern Gulf of Mexico in the aftermath of Hurricane Harvey. Limnol. Oceanogr. 2021, 9999, 1-18. [CrossRef] 